Market and Competition Law Review / VOLUME I / No. 2 / OCTOBER 2017

\title{
EU Law Restitution Revisited: In Search of Lost Criteria*
}

Magnus Strand ${ }^{* *}$

ABSTRACT: Since Francovich it seems the damages remedy has become The Remedy for individuals suffering economic loss by reason of EU law infringements by Member States. There is however an alternative to damages in private enforcement of EU law, in fact an antecedent to Francovich: Restitution by reason of a breach of EU law. Nonetheless, the criteria for restitution from a Member State, by reason of its breach of EU law, still remain neglected in comparison to the close attention and debate surrounding the criteria for the damages action against Member States. The purpose of this contribution is thus to identify and to discuss the distinctive elements of restitution as a remedy in the event of a breach of EU law by a Member State. Focus is on the very criteria that constitute legal basis for a claim of restitution from a Member State under EU law and the extent to which those criteria should be governed by EU law or by national law. Less attention is devoted to exceptions from liability to make restitution, although their existence in the case law is duly noted. The criteria identified in the case law are (1) the existence of a substantive right conferred on the claimant by EU law, (2) the existence of a payment from the claimant, collected by or on behalf of the Member State, (3) the incompatibility of the basis of that payment with EU law, and (4) that the payment follows as an inevitable consequence of the breach of EU law by the Member State. Case law hints on the more precise legal content of the criteria are examined in an attempt to shed light on their proper interpretation and application. It is noted that the second and third criteria cannot, on the basis of existing case law, be defined with precision. In that connection it is discussed whether the second criterion should be subdivided into two criteria: Impoverishment of the claimant and enrichment of the Member State. As regards to the fourth criterion it is noted that it is

\footnotetext{
* Date of Reception: 08 July 2017. Date of Acceptance: 26 July 2017.

** Dr jur. in European law, Senior lecturer in commercial law, Department of Business Studies, Uppsala University. 75120 Uppsala, Sweden, magnus.strand@fek.uu.se.
} 
uncertain whether it applies at all. Finally it is submitted that some of the difficulties could be overcome if the Court of Justice were to distinguish clear cases of repayment of charges levied by a Member State institution or agency in breach of EU law from more difficult cases of possible liability by reason of the unjust enrichment of Member States.

KEYWORDS: EU law, Restitution, Member State liability, criteria, recovery of unlawful charges

\section{Introduction}

Since Francovich ${ }^{1}$ it seems the damages remedy has become The Remedy for individuals suffering economic loss by reason of EU law infringements by Member States. The dominance of the damages remedy is also reflected in horizontal private enforcement, as in the recent harmonization of competition damages actions under Directive 2014/104. ${ }^{2}$ Notwithstanding this prevalent damages hegemony, there was indeed private enforcement of EU law before Francovich, and the action par excellence in those days was restitution by reason of a breach of EU law. The Court of Justice indeed held as early as in 1960, in Humblet, that there is a right to repayment of charges levied in breach of EU law. ${ }^{3}$

The right to repayment for individuals burdened by charges levied by a Member State in breach of EU (or rather, then, Community) law was referred to explicitly by the Court of Justice in Pigs and Bacon. ${ }^{4}$ The criteria for such restitution were not elaborated by the Court, however. In fact, the criteria for restitution from a Member State, by reason of its breach of EU law, still remain neglected in comparison to the close attention and debate surrounding the criteria for a damages action for the same reason. ${ }^{5}$ One might wish to argue that this is because restitution is a no-brainer: If a

\footnotetext{
${ }^{1}$ Judgment of 19 November 1991, Francovich, joined cases C-6/90 and C-9/90, EU:C:1991:428.

${ }^{2}$ Directive 2014/104/EU of the European Parliament and of the Council of 26 November 2014 on certain rules governing actions for damages under national law for infringements of the competition law provisions of the Member States and of the European Union [2014] OJ L 349/1.

${ }^{3}$ Judgment of 16 December 1960, Humblet, 6/60, EU:C:1960:48, 569, on reimbursement following a breach of the ECSC Treaty.

${ }^{4}$ Judgment of 26 June 1979, Pigs and Bacon, 177/78, EU:C:1979:164.

${ }^{5}$ On the damages action see e.g. Andrea Biondi and Martin Farley, The Right to Damages in European Law, Kluwer European Law Collection (Alphen aan den Rijn: Kluwer Law International, 2009), The Action for Damages in Community Law, ed. Ton Heukels and Alison McDonnell
} 
charge has been levied in breach of EU law, it must be repaid. The only elements to be proven would, at a glance, be that a charge has been paid and that the levying of that charge by the Member State was contrary to EU law. It should consequently be for the national courts to apply the national version of the Roman condictio indebiti, i.e. the repayment of sums paid but not due, ${ }^{6}$ albeit under the ever-wary eyes of the two EU law watchdogs: the principles of equivalence and effectiveness. ${ }^{7}$ And all should be well.

Things are not quite so simple, however. First of all, any version of the action for sums paid but not due will recognise a number of exceptions to the main rule of repayment. Hence the Court of Justice has found it necessary to consider a number of circumstances where such exceptions should, under national law, apply. The aforementioned Pigs and Bacon itself offers an example: The claimant had not only paid an unlawful levy but had also received a subsidy which the levy at issue was designed to finance. With regard to such circumstances the Court of Justice indicated that it would be compatible with EU law for the sums paid by way of subsidy to be set off against the repayment due. The Court held - more abstractly - that it was for the national court to assess, according to its national law, in each individual case, whether and to what extent the levy paid to the Member State might be recovered. ${ }^{8}$ In other words, exceptions from repayment were and are possible. ${ }^{9}$

Secondly, this author would not agree that restitution is a no-brainer. In fact, if it ever was, recent case law has made it much less so. Most importantly the recent developments of the "exclusionary effect" of EU

(Alphen aan den Rijn: Kluwer Law, 1997), and Pekka Aalto, Public Liability in EU Law: Brasserie, Bergaderm and Beyond (Oxford: Hart Publishing, 2011).

${ }^{6}$ As highlighted by Lesley Jane Smith, "A European Concept of Condictio Indebiti?", Common Market Law Review 19, no. 2 (1982): 284-285.

${ }^{7}$ On the principles of equivalence and effectiveness and their place within the overall framework of effective judicial protection under EU law see section 2 below.

${ }^{8}$ Judgment of 26 June 1979, Pigs and Bacon, 177/78, EU:C:1979:164, paragraph 25.

9 The Court has more recently held that the direct passing-on to a purchaser of the tax wrongly levied constituted the sole exception to the right to reimbursement of taxes levied in breach of EU law; Judgment of 6 September 2011, Lady \& Kid, C-398/09, EU:C:2011:540, paragraph 20; and Judgment of 24 November 2016, SECIL, C-464/14, EU:C:2016:896, paragraph 165. However, the Court has not been entirely consistent in this point, cf. Judgment of 16 May 2013, Alakor, C-191/12, EU:C:2013:315 and Judgment of 15 October 2014, Nicula, C-331/13, EU:C:2014:2285. Cf. also the discussion in Magnus Strand, The Passing-On Problem in Damages and Restitution under EU Law, Elgar European Law and Practice Series (Cheltenham: Edward Elgar Publishing, 2017), paragraphs 5.164-5.178. 
law induce analysis of the quality of a breach of EU law in order for that breach to trigger a right to repayment. Moreover, in some cases the Court of Justice has needed to address another complication in restitution which is perhaps less apparent then those already mentioned: The proximity of the connection between a transaction (i.e. the levying of a charge in breach of EU law) and the economic burden suffered by the claimant. The Court of Justice has held in this regard that an action for restitution by reason of a breach of EU law presupposes that the loss alleged by the claimant is an "inevitable consequence" of the breach committed by the defendant Member State. ${ }^{10}$ The substantive legal meaning of this holding will be discussed further below.

The purpose of this contribution is thus to identify and to discuss the distinctive elements of restitution as a remedy in the event of a breach of EU law by a Member State. ${ }^{11}$ Focus will be on the very criteria that constitute legal basis for a claim of restitution from a Member State under EU law, and on the extent to which those criteria should be governed by EU law or by national law. Less attention will be devoted to exceptions from liability to make restitution, although their existence in the case law must be duly noted.

For clarity, this contribution is intended neither to trace the origins of restitution back to Roman condictiones, ${ }^{12}$ nor to discuss the Aristotelian or other concepts of justice underlying it..$^{13}$ It is not even my intention to use

\footnotetext{
${ }^{10}$ Judgment of 12 December 2006, Test Claimants in the FII Group Litigation, C-446/04, EU:C:2006:774, paragraph 207.

${ }^{11}$ Restitutionary actions against the EU have been recognized in Judgment of 10 October 2001, Corus UK, T-171/99, EU:T:2001:249 (repayment of sums not due); and Judgment of 16 December 2008, Masdar, C-47/07 P, EU:C:2008:726 (unjust enrichment). Restitution as an alternative to damages in the event of a breach of competition law, i.e. a horizontal restitutionary action, has been discussed by Magnus Strand, "Beyond the Competition Damages Directive: What Room for Competition Law Restitution?", in Harmonising EU Competition Litigation: The New Directive and Beyond, Swedish Studies in European Law, vol. 8, ed. Maria Bergström, Marios Iacovides and Magnus Strand (Oxford: Hart Publishing, 2016). See also Judgment of 17 July 1997, GT-Link, C-242/95, EU:C:1997:376. In this competition case, however, the restitutionary action was brought against a Member State.

${ }^{12}$ For an account of the Roman and European legal history of restitution, see Reinhard Zimmermann, The Law of Obligations: Roman Foundations of the Civilian Tradition (Oxford: Oxford University Press, 1996), Part VII; or, for a concise account, Konrad Zweigert and Hein Kötz, An Introduction to Comparative Law (Oxford: Oxford University Press, 1998), ch. 38.

${ }^{13}$ A good starting point for those interested is Philosophical Foundations of The Law of Unjust Enrichment, ed. Robert Chambers, Charles Mitchell and James Penner (Oxford: Oxford University Press, 2009).
} 
comparative legal studies, at least not to any greater extent; for it is only with great caution, if at all, that conclusions can be drawn for the purposes of EU private law from national traditions of private law, notwithstanding the existence of common features in European jurisdictions derived ultimately from Roman law. For example, private unjust (or unjustified ${ }^{14}$ ) enrichment law does not necessarily apply to repayment actions brought against the State. The degree to which it does seems to vary considerably between Member States. ${ }^{15}$ Here, instead, focus will remain on EU law, and the legal source materials used are predominantly case law of the Court of Justice or other EU law materials. European private law materials will be taken into account as a source of inspiration only. With this said, it will admittedly be an important point of departure in this contribution that private law of restitution has much to offer public law of restitution.

Before presenting and discussing the details of restitutionary liability of Member States under EU law (in sections 3 and 4), it is warranted to prepare the ground by dedicating a few words to the general approach of the Court of Justice in respect of private enforcement actions against Member States (in section 2).

\section{Effective judicial protection and private enforcement remedies}

The EU law evergreen of effective judicial protection is a perilous concept which threatens to consume anyone who tries to understand it, and to invade and suffocate any text for which it is crucial. There is no way around it, but in order to maintain focus in this contribution it will be necessary to

\footnotetext{
${ }^{14}$ In European private law discussions the term "unjustified" enrichment is perhaps more commonly used than "unjust" enrichment. The concept of unjustified enrichment usually indicates that an enrichment of the defendant is unjustified if there is no valid legal basis for the defendant to retain it. The concept of unjust enrichment has more often been used in common law countries, where it has traditionally been for the claimant to identify an "unjust factor" that has given rise to the enrichment of the defendant. See further Francesco Giglio, "A Systematic Approach to 'Unjust' and 'Unjustified' Enrichment", Oxford Journal of Legal Studies 23, no. 3 (2003): 455-482. In the case law of the EU Courts, however, no such distinction seems to have been upheld. In recent case law the Court of Justice has quite consistently preferred the term "unjust enrichment". Therefore, that term is used consistently in this text, regardless of the respective merits of the two alternatives. No specific distinction is intended, and although comparisons are made with European private law the concept is still interpreted as an autonomous EU law concept.

${ }^{15}$ In many jurisdictions, public law provisions with varying content will apply to such actions; see Principles, Definitions and Model Rules of European Private Law: Draft Common Frame of Reference (DCFR) Full Edition (6 vols), ed. Christian von Bar and Eric Clive (Munich: Sellier European Law Publishers, 2009) Article VII. - 7:103 with the accompanying Comments and Notes.
} 
cut a few corners and simply present the view of effective judicial protection in the EU that underpins the argumentation to follow.

Judicial protection in a broad sense should be distinguished from the more narrowly defined principles, developed by the Court of Justice, that serve the aim of judicial protection in the EU law system. Judicial protection in a broad sense thus designates the general interest of ensuring that rights conferred on individuals by the EU Treaties or secondary legislation are properly enforceable before courts and/or administrative bodies. This interest is safeguarded in EU law by a number of legal principles, doctrines and mechanisms that have developed in the case law, including EU law primacy, direct effect and other invocabilités of EU law, the principles of equivalence and effectiveness, and the more specific principle of effective judicial protection which is now enshrined in Article 47 of the EU Charter. This more specific principle in turn encompasses, or overlaps, another range of rights and principles. These include the right to a fair trial and the rights of defence, which are both crucial in criminal proceedings, and the right to an effective remedy, which is central also to private enforcement of EU law. ${ }^{16}$

In sections below we will consider the role of concepts such as direct effect, other invocabilités of EU law, and of the principles of equivalence and effectiveness in the context of restitutionary actions against a Member State. The right to an effective remedy is also of interest. This right is not only expressed in Article 47(1) of the Charter, but also in Article 19(1) of the Treaty on European Union. It applies whenever a substantive right has been conferred on a party by EU law, and it applies against the party holding the obligation corresponding to that substantive right. The legal significance of the right to an effective remedy is that there must be a properly effective course of action available for the enforcement of the substantive right at issue. In the case law, the Court of Justice has therefore intervened in situations where it has seemed that a claimant had no effective remedy at their disposal in the national law context with which to enforce the substantive right conferred upon them by EU law. In such situations, the Court has held, an effective remedy must be made available to the claimant

\footnotetext{
${ }^{16}$ For an analysis of the various aspects of Article 47, see Pekka Aalto, et al., "Article 47 - Right to an Effective Remedy and to a Fair Trial". In The EU Charter of Fundamental Rights: A Commentary, ed. Steve Peers, et al. (Munich: Verlag CH Beck/Oxford: Hart Publishing/Baden-Baden: Nomos, 2014).
} 
by the national courts or administrations. ${ }^{17}$ Examples of such intervention can be seen in Factortame $I^{18}$ Francovich $^{19}$ and Courage. ${ }^{20}$

The point to be made in this context is that the default position in private enforcement of EU law, before the national courts and administrations, ${ }^{21}$ is that the existing remedies in the Member States should suffice for effective judicial protection of EU law rights. The EU law system thus presupposes that, in the event of a breach of EU law, the Member States will each have a system in place that is capable of providing the party suffering from such a breach of EU law with effective remedies. Only when this presupposition proves to fail will the Court of Justice intervene, armed with the EU law right to an effective remedy, and order the introduction of a remedy capable of ensuring the effective judicial protection of the substantive right infringed.

The development of case law on situations where an effective remedy has been missing has nonetheless, as a side-effect, produced a set of remedies that the Court of Justice requires for the Member States to always have in place in the event of a breach of EU law. Furthermore, the Court has considered itself compelled to set a number of minimum standards for those remedies in order for them to be "effective" within the meaning of EU law. The most striking example of this is perhaps the development of the criteria for Member State liability in damages. ${ }^{22}$

The tool most commonly employed by the Court of Justice to promote the effectiveness of remedies is the dual test composed by the principles of equivalence and effectiveness. There is no room here to do justice to the multi-faceted case law of the Court of Justice on its principles of equivalence and effectiveness, other than the examples that will be provided in

\footnotetext{
${ }^{17}$ See e.g. Judgment of 13 March 2007, Unibet, C-432/05, EU:C:2007:163, paragraphs 40-42 and Judgment of 3 October 2013, Inuit, C-583/11 P, EU:C:2013:625, paragraph 104.

${ }^{18}$ Judgment of 19 June 1990, Factortame, C-213/89, EU:C:1990:257.

${ }^{19}$ Judgment of 19 November 1991, Francovich, joined cases C-6/90 and C-9/90, EU:C:1991:428.

${ }^{20}$ Judgment of 20 September 2001, Courage v Crehan, C-453/99, EU:C:2001:465.

${ }^{21}$ Consequently, enforcement by private individuals against the EU, which falls under the exclusive jurisdiction of the EU Courts pursuant to Articles 263(4) and 268 TFEU, is disregarded here. However, cf. Judgment of 16 December 2008, Masdar, C-47/07 P, EU:C:2008:726 where the right to an effective remedy prompted the Court of Justice to allow an action of unjust enrichment against the EU notwithstanding that Article 340(2) TFEU speaks only of damages.

${ }^{22}$ See Judgment of 19 November 1991, Francovich, joined cases C-6/90 and C-9/90, EU:C:1991:428; Judgment of 5 March 1996, Brasserie du Pêcheur, joined cases C-46/93 and C-48/93, EU:C:1996:79; but in particular Judgment of 8 October 1996, Dillenkofer, joined cases C-178/94, C-179/94, C-188/94, C-189/94 and C-190/94, EU:C:1996:375.
} 
the discussion below. In essence the role of these rules is to ensure fairness in the general context of national law conditions, procedural and other, for the exercise of remedies used to enforce rights conferred by EU law. Hence it has been argued that they operate on a different level than the right to an effective remedy: Where there is a right, there must first be a remedy (pursuant to the right to an effective remedy). Secondly, the conditions for the exercise of that remedy must be compatible with the principles of equivalence and effectiveness. ${ }^{23}$

In brief, the principle of equivalence provides that national rules and conditions governing actions based on EU law must not be less favourable than those governing similar domestic actions, while the principle of effectiveness stipulates that national rules governing actions based on EU law must not render the exercise of rights conferred on individuals by EU law virtually impossible or excessively difficult. ${ }^{24}$ In the first cases, Rewe and Comet, the Court seemed content to entrust the national courts with the final assessment of applicable national laws and procedures against this standard. Since then, the intensity of the Court's review has increased, and now the Court has been known to make quite stringent interpretations of the impact of the two principles in the main proceedings. ${ }^{25}$

The interrelationship of these various rights, principles and doctrines of effective judicial protection is not very clear. The Court of Justice has

\footnotetext{
${ }^{23}$ This three-tier model (rights, remedies, conditions/procedures) is adopted from Walter van Gerven, "Of Rights, Remedies and Procedures", Common Market Law Review 37, no. 3 (2000): 502-504. For a recent contribution building on the van Gerven model see Nina Półtorak, European Union Rights in National Courts (Alphen aan den Rijn: Wolters Kluwer, 2015).

${ }^{24}$ The development of these principles began in Judgment of 16 December 1976, Rewe-Zentralfinanz, 33/76, EU:C:1976:188; and Judgment of 16 December 1976, Comet, 45/76, EU:C:1976:191. Important case law on the principle of equivalence includes Judgment of 15 September 1998, Edis, C-231/96, EU:C:1998:401; and Judgment of 1 December 1998, Levez, C-326/96, EU:C:1998:577. Central case law on the principle of effectiveness includes Judgment of 14 December 1995, Peterbroeck, C-312/93, EU:C:1995:437; and Judgment of 18 March 2010, Alassini, joined cases C-317/08 - C-320/08, EU:C:2010:146. For further analysis see e.g. Anthony Arnull, The European Union and its Court of Justice, Oxford EC Law Library (Oxford: Oxford University Press, 2006), ch. 9 or Michael Dougan, National Remedies before the Court of Justice: Issues of Harmonisation and Differentiation, Modern Studies in European Law (Oxford: Hart Publishing, 2004), ch. 5.

${ }^{25}$ With regard to the principle of equivalence, see e.g. Judgment of 26 January 2010, Transportes Urbanos, C-118/08, EU:C:2010:39. For an example with the principle of effectiveness, see e.g. Judgment of 20 October 2011, Danfoss, C-94/10, EU:C:2011:674, where this principle was, as it seems, applied to overcome a hindrance caused by factual circumstances rather than by the legal context as such.
} 
in fact been somewhat inconsistent, which has triggered further confusion. ${ }^{26}$ This general presentation hopefully serves to give some background to the approach of the Court of Justice regarding national remedies for the enforcement of EU law rights. In sum, and simplified, the Member States are trusted to provide sufficient remedies. In the event that they fail to do so, the EU law package of effective judicial protection will apply. The Court of Justice may thus call upon the Member State at issue to introduce appropriate remedies. Further, the conditions of national law for the exercise of the available or introduced remedies are subject to scrutiny under the principles of equivalence and effectiveness. Next, we will see how these principles of effective judicial protection have played out in the development of restitutionary liability for Member States.

\section{The remedy of restitution from a Member State}

\section{a. History of the remedy}

Even though the Member States are, by and large, entrusted with providing sufficient remedies for the private enforcement of EU law, the Court of Justice has held on occasion that a specific remedy must be available to claimants in a certain situation. As regards restitution from a Member State, it was mentioned above that a right to repayment of charges levied in breach of (now) EU law was first established in this manner in Pigs and Bacon, where the Court held:

In principle any trader who is required to pay the levy has therefore the right to claim the reimbursement of that part of the levy which is thus devoted to purposes incompatible with Community law. ${ }^{27}$

\footnotetext{
${ }^{26}$ Compare e.g. the holdings in Judgment of 13 March 2007, Unibet, C-432/05, EU:C:2007:163, paragraphs 42-43; Judgment of 15 April 2008, Impact, C-268/06, EU:C:2008:223, paragraph 47; Judgment of 29 October 2009, Virginie Pontin, C-63/08, EU:C:2009:666, paragraph 44; and Judgment of 18 March 2010, Alassini, joined cases C-317/08 - C-320/08, EU:C:2010:146, paragraphs 49 and 61-66. For further reading, see e.g. Michael Dougan, "The Vicissitudes of Life at the Coalface: Remedies and Procedures for Enforcing Union Law before the National Courts", in The Evolution of EU Law, ed. Paul Craig and Gráinne de Búrca (Oxford: Oxford University Press, 2011) and Sacha Prechal and Rob Widdershoven, "Effectiveness or Effective Judicial Protection: A Poorly Articulated Relationship", in Today's Multi-Layered Legal Order: Current Issues and Perspectives. Liber Amicorum in Honour of Arjen W.H. MEIJ, ed. Tristan Baumé, et al. (Zutphen: Paris Legal Publishers, 2011).

${ }^{27}$ Judgment of 26 June 1979, Pigs and Bacon, 177/78, EU:C:1979:164, paragraph 25.
} 
The result of Pigs and Bacon was that sums paid but not due under EU law were, in principle, recoverable from Member States as a matter of EU law. ${ }^{28}$ This was the crucial starting point for an abundance of case law to follow, in which the Court has elaborated on details of such repayment. The question that arose from Pigs and Bacon, however, was what exactly was meant by a right to reimbursement "in principle"?

It was clarified in subsequent case law that the meaning of a right "in principle", as declared by the Court of Justice, did not exclude the possibility of national substantive and procedural rules legitimately limiting the exercise of such a right. Of course, such national limitations have remained subject to the dual test of the EU principles of equivalence and effectiveness. ${ }^{29}$ Thus, the EU law right to reimbursement is to be enforced within the legal framework of national law, using national restitutionary actions of public liability that are nonetheless subject to EU law scrutiny.

Interestingly, charges have also been collected by national authorities on behalf of the EU, or pursuant to an EU law instrument or provision which is subsequently declared invalid. Under such circumstances the issue has arisen whether there is a parallel action for restitution against the EU for the repayment of such charges. ${ }^{30}$ In early case law an action for the recovery of such charges brought against the EU was admissible before the Court of Justice, but it was held by the Court that claimants must first exhaust the remedies available under national law against the collecting national authority. ${ }^{31}$ Pigs and Bacon all but extinguished this possibility of

\footnotetext{
${ }^{28}$ It however remained for the national court to decide to what extent there could be recovery and in particular whether certain sums received by the claimant could be set off against the recoverable amount.

${ }^{29}$ The applicability of the EU law principles of equivalence and effectiveness in this context has been verified by the Court of Justice in e.g. Judgment of 27 February 1980, Just, 68/79, EU:C:1980:57, paragraph 25; Judgment of 9 November 1983, San Giorgio, 199/82, EU:C:1983:318, paragraph 12; Judgment of 25 February 1988, Bianco, joined cases 331/85, 376/85 and 378/85, EU:C:1988:97, paragraph 10; Judgment of 21 September 2000, Michailidis, joined cases C-441/98 and C-442/98, EU:C:2000:479, paragraph 36; Judgment of 2 October 2003, Weber's Wine World, C-147/01, EU:C:2003:533, paragraph 103; Judgment of 15 September 2011, Accor, C-310/09, EU:C:2011:581, paragraph 79; Judgment of 20 October 2011, Danfoss, C-94/10, EU:C:2011:674, paragraph 24; and Judgment of 16 May 2013, Alakor, C-191/12, EU:C:2013:315, paragraph 26.

${ }^{30}$ As regards repayment from an EU institution without any Member State acting as intermediary, see Judgment of 10 October 2001, Corus UK, T-171/99, EU:T:2001:249. The Court of Justice has moreover held in Judgment of 16 December 2008, Masdar, C-47/07 P, EU:C:2008:726 that EU institutions can be held liable for unjust enrichment, but that seems to have been a rare instance of private law liability of the EU rather than public law liability.

${ }^{31}$ Judgment of 14 July 1967, Firma E. Kampffmeyer, joined cases 5, 7 and 13 to 24/66, EU:C:1967:31.
} 
EU liability, and in more recent case law it has been established that claims belonging to this category fall under the exclusive jurisdiction of national courts, irrespective of the fact that the underlying unlawfulness of the levy is attributable in whole or in part to the EU..$^{32}$ The Court of Justice has consequently safeguarded the EU purse from restitutionary liability arising from the levying of charges by national authorities on behalf of the EU, leaving it to the Member States to pay for any and all reimbursements. Although a Member State could in theory be expected to bring an action of recourse against the EU by reason of having reimbursed claimants, this does not seem to have occurred. ${ }^{33}$

As is apparent, the details of the action for repayment of charges levied in breach of EU law have never been subject to harmonization through EU legislation although such harmonization has been called for by commentators. ${ }^{34}$ In fact the Court itself declared in Express Dairy Foods that it was "regrettable" that there were no EU rules harmonizing procedure and time-limits that might bar claims. ${ }^{35}$ Nonetheless the Court has taken some steps to eliminate national rules and practices that would hamper the exercise of the right to reimbursement, of which a few will be mentioned here. First, in San Giorgio, the Court of Justice put further emphasis on the need to respect the right to repayment by holding (as has been cited in many subsequent cases) that entitlement to the repayment of charges levied by a Member State contrary to the rules of EU law is a consequence of, and an adjunct to, the rights conferred on individuals by the provisions prohibiting such charges. ${ }^{36}$ Second, a well-known strand of case law on the

32 Judgment of 13 March 1992, Industrie- en Handelsonderneming Vreugdenhil, C-282/90, EU:C:1992:124, paragraph 12; Judgment of 27 September 2007, Ikea Wholesale, C-351/04, EU:C:2007:547, paragraphs 67-68; Judgment of 18 March 2010, Trubowest Handel, C-419/08 P, EU:C:2010:147, paragraphs 23-26. For a critical discussion see Andrea Biondi and Martin Farley, The Right to Damages in European Law, 178-80.

${ }^{33}$ Andrea Biondi and Martin Farley, The Right to Damages in European Law, 88 consider it unlikely "in view of the overall judicial scheme provided" by the EU Treaties for Member States to bring a claim against the EU. See also Koen Lenaerts, Ignace Maselis and Kathleen Gutman, EU Procedural Law, ed. Janek Tomasz Nowak, Oxford EU Law Library (Oxford: Oxford University Press, 2014), 495.

${ }^{34}$ E.g. Andrea Biondi and Lindsay Johnson, "The Right to Recovery of Charges Levied in Breach of Community Law: No Small Matter", European Public Law 4, no. 3 (1998): 313.

${ }^{35}$ Judgment of 12 June 1980, Express Dairy Foods, 130/79, EU:C:1980:155, paragraph 12.

${ }^{36}$ Judgment of 9 November 1983, San Giorgio, 199/82, EU:C:1983:318, paragraph 12. The formula reappears in, e.g., Judgment of 14 January 1997, Comateb, joined cases C-192/95 - C-218/95, EU:C:1997:12, paragraph 20; Judgment of 17 July 1997, Texaco, joined cases C-114/95 and C-115/95, 
impact of the principles of equivalence and effectiveness has concerned time-limits in national law applicable to repayment actions. ${ }^{37}$ In brief, the Court of Justice has ruled that the laying down of reasonable limitation periods is not contrary to the principles of equivalence and effectiveness, "even if the expiry of those periods necessarily entails the dismissal, in whole or in part, of the action brought" ${ }^{38}$ Third, the Court has step-by-step limited the availability of a defence of unjust enrichment and/or passingon against actions for repayment of unlawful charges, also by reference in particular to the principle of effectiveness. ${ }^{39}$

The second and third issues indicated are of less relevance to this presentation, but the first indicates a criterion for restitutionary liability of Member States: The existence of a substantive right on behalf of the claimant. This will be elaborated below. In that connection however, it should also be considered whether the restitutionary liability of Member States pertains only to a certain field of substantive EU policy. This will be explored next.

\section{b. Substantive scope of the remedy}

As should be apparent from the above, the case law of the Court of Justice on restitution from a Member State has, more specifically, concerned repayment of charges levied in breach of internal market law. It might in this context be asked whether the case law at issue should not be read in that substantive context, and that the suggestion that this case law indicates that there is a general remedy of restitution from Member States is going a bridge too far. In that vein, Dougan has argued that any form of harmonization of remedies should be "sectoral", that is, designed to apply to specific and substantive EU policy areas (e.g. environmental

EU:C:1997:371, paragraphs 40 and 45; Judgment of 17 July 1997, GT-Link, C-242/95, EU:C:1997:376, paragraph 58; and Judgment of 2 December 1997, Fantask, C-188/95, EU:C:1997:580, paragraph 38. ${ }^{37}$ The first of these cases were Judgment of 16 December 1976, Rewe-Zentralfinanz, 33/76, EU:C:1976:188 and Judgment of 16 December 1976, Comet, 45/76, EU:C:1976:191.

${ }^{38}$ Judgment of 17 July 1997, Haahr Petroleum, C-90/94, EU:C:1997:368, paragraph 48. See also Judgment of 15 September 1998, Edis, C-231/96, EU:C:1998:401, paragraph 20 and the case law there cited. For an extensive overview and discussion, see Angela Ward, Judicial Review and the Rights of Private Parties in EU Law (Oxford: Oxford University Press, 2007), ch. 4B.

${ }^{39}$ See in particular Judgment of 14 January 1997, Comateb, joined cases C-192/95 - C-218/95, EU:C:1997:12; and Judgment of 6 September 2011, Lady \& Kid, C-398/09, EU:C:2011:540. As mentioned in note 9 the Court has not been consistent on the interrelationship of passing-on and unjust enrichment. For an analysis of the defence of unjust enrichment and/or passing-on see Magnus Strand, The Passing-On Problem.... 
law, consumer law, and the like). ${ }^{40}$ Arguably the approach advocated by Dougan is the one that has been followed by the EU legislature, as we have seen sector-specific private enforcement rules designed for competition law infringements, ${ }^{41}$ intellectual property intrusions, ${ }^{42}$ discrimination in employment, ${ }^{43}$ and more. Where such a sectoral legislative framework is in place, the Court of Justice also seems to have been inclined to develop case law which has been specific to that legislative context. ${ }^{44}$

What about the EU case law on restitution from a Member State? Is it confined to specific areas of EU policy? The following simple table, which is not intended to be exhaustive, illustrates (albeit roughly) the internal market law issues concerned in the case law:

\begin{tabular}{|l|l|l|}
\hline \multicolumn{1}{|c|}{ Case no. and name } & \multicolumn{1}{|c|}{$\begin{array}{c}\text { Main EU law } \\
\text { provision breached }\end{array}$} & \multicolumn{1}{c|}{ Policy area at stake } \\
\hline $\begin{array}{l}\text { Judgment of 26 June 1979, Pigs and } \\
\text { Bacon, 177/78, EU:C:1979:164 }\end{array}$ & $\begin{array}{l}\text { Article 40 EEC (now } 40 \\
\text { TFEU) }\end{array}$ & Common agriculture policy \\
\hline $\begin{array}{l}\text { Judgment of 27 February 1980, Just, } \\
\text { 68/79, EU:C:1980:57 }\end{array}$ & $\begin{array}{l}\text { Article 95 EEC (now 110 } \\
\text { TFEU) }\end{array}$ & $\begin{array}{l}\text { Non-discrimination in } \\
\text { taxes }\end{array}$ \\
\hline $\begin{array}{l}\text { Judgment of the Court of 27 March } \\
\text { 1980, Denkavit Italiana, 61/79, } \\
\text { EU:C:1980:100 }\end{array}$ & Article 13 EEC (repealed) & Customs union \\
\hline $\begin{array}{l}\text { Judgment of 12 June 1980, } \\
\text { Express Dairy Foods, 130/79, } \\
\text { EU:C:1980:155 }\end{array}$ & $\begin{array}{l}\text { Article 1(2)(b) of } \\
\text { Regulation No 974/71 }\end{array}$ & Common agriculture policy \\
\hline $\begin{array}{l}\text { Judgment of 9 November 1983, San } \\
\text { Giorgio, 199/82, EU:C:1983:318 }\end{array}$ & Article 13 EEC (repealed) & Customs union \\
\hline $\begin{array}{l}\text { Judgment of 13 December } \\
\text { 1983, Apple and Pear, 222/82, } \\
\text { EU:C:1983:370 }\end{array}$ & $\begin{array}{l}\text { Articles 30 and 34 EEC } \\
\text { (now 34 and 35 TFEU) }\end{array}$ & $\begin{array}{l}\text { Prohibition of quantitative } \\
\text { restrictions }\end{array}$ \\
\hline
\end{tabular}

\footnotetext{
${ }^{40}$ Michael Dougan, National Remedies, 389-395.

${ }^{41}$ Directive 2014/104/EU of the European Parliament and of the Council of 26 November 2014 on certain rules governing actions for damages under national law for infringements of the competition law provisions of the Member States and of the European Union [2014] OJ L 349/1.

${ }^{42}$ Directive 2004/48/EC of the European Parliament and of the Council of 29 April 2004 on the enforcement of intellectual property rights [2004] OJ L 157/45.

${ }^{43}$ Directive 2006/54/EC of the European Parliament and of the Council of 5 July 2006 on the implementation of the principle of equal opportunities and equal treatment of men and women in matters of employment and occupation (recast) [2006] OJ L 204/23.

${ }^{44}$ See for example the specific development of the meaning of sanctions that can "guarantee real and effective judicial protection and have a deterrent effect" in discrimination cases such as Judgment of 10 April 1984, von Colson, 14/83, EU:C:1984:153; Judgment of 2 August 1993, Marshall II, C-271/91, EU:C:1993:335; Judgment of 22 April 1997, Draehmpaehl, C-180/95, EU:C:1997:208; and Judgment of 25 April 2013, Asociaţia Accept, C-81/12, EU:C:2013:275.
} 


\begin{tabular}{|c|c|c|}
\hline Case no. and name & $\begin{array}{c}\text { Main EU law } \\
\text { provision breached }\end{array}$ & Policy area at stake \\
\hline $\begin{array}{l}\text { Judgment of } 2 \text { February 1988, } \\
\text { Barra, 309/85, EU:C:1988:42 }\end{array}$ & $\begin{array}{l}\text { Article } 7 \text { EEC (now } 18 \\
\text { TFEU) }\end{array}$ & $\begin{array}{l}\text { Non-discrimination of } \\
\text { persons }\end{array}$ \\
\hline $\begin{array}{l}\text { Judgment of } 25 \text { February } 1988, \\
\text { Bianco, joined cases 331/85, 376/85 } \\
\text { and 378/85, EU:C:1988:97 }\end{array}$ & $\begin{array}{l}\text { Articles } 9 \text { and } 12 \text { EEC (now } \\
28 \text { and } 30 \text { TFEU) }\end{array}$ & Customs union \\
\hline $\begin{array}{l}\text { Judgment of } 6 \text { July 1995, } B P \\
\text { Soupergaz, C-62/93, EU:C:1995:223 }\end{array}$ & $\begin{array}{l}\text { Articles } 2,11 \text { and } 17 \text { of } \\
\text { Directive } 77 / 388 / \text { EEC } \\
\text { (Sixth VAT Dir) }\end{array}$ & Common system of VAT \\
\hline $\begin{array}{l}\text { Judgment of } 14 \text { January 1997, } \\
\text { Comateb, joined cases C-192/95 - } \\
\text { C-218/95, EU:C:1997:12 }\end{array}$ & $\begin{array}{l}\text { Articles } 9 \text { and } 12 \text { EEC (now } \\
28 \text { and } 30 \text { TFEU) }\end{array}$ & Customs union \\
\hline $\begin{array}{l}\text { Judgment of } 17 \text { July 1997, Haahr } \\
\text { Petroleum, C-90/94, EU:C:1997:368 }\end{array}$ & $\begin{array}{l}\text { Article } 95 \text { EEC (now } 110 \\
\text { TFEU) }\end{array}$ & $\begin{array}{l}\text { Non-discrimination in } \\
\text { taxes }\end{array}$ \\
\hline $\begin{array}{l}\text { Judgment of } 17 \text { July 1997, Texaco, } \\
\text { joined cases C-114/95 and } \\
\text { C-115/95, EU:C:1997:371 }\end{array}$ & $\begin{array}{l}\text { Article } 95 \text { EEC (now } 110 \\
\text { TFEU) }\end{array}$ & $\begin{array}{l}\text { Non-discrimination in } \\
\text { taxes }\end{array}$ \\
\hline $\begin{array}{l}\text { Judgment of } 17 \text { July 1997, GT-Link, } \\
\text { C-242/95, EU:C:1997:376 }\end{array}$ & $\begin{array}{l}\text { Article } 95 \text { but also } 90 \text { and } \\
86 \text { EEC (now 110, } 106 \text { and } \\
102 \text { TFEU) }\end{array}$ & $\begin{array}{l}\text { Non-discrimination in taxes } \\
\text { and rules on competition }\end{array}$ \\
\hline $\begin{array}{l}\text { Judgment of } 2 \text { December 1997, } \\
\text { Fantask, C-188/95, EU:C:1997:580 }\end{array}$ & $\begin{array}{l}\text { Article } 12 \text { of Directive } \\
69 / 335 / \mathrm{EEC}\end{array}$ & $\begin{array}{l}\text { Harmonization of indirect } \\
\text { taxes }\end{array}$ \\
\hline $\begin{array}{l}\text { Judgment of } 15 \text { September 1998, } \\
\text { Edis, C-231/96, EU:C:1998:401 }\end{array}$ & $\begin{array}{l}\text { Articles } 10 \text { and } 12 \text { of } \\
\text { Directive } 69 / 335 / \text { EEC }\end{array}$ & $\begin{array}{l}\text { Harmonization of indirect } \\
\text { taxes }\end{array}$ \\
\hline $\begin{array}{l}\text { Judgment of } 15 \text { September } \\
\text { 1998, Ansaldo Energia, joined } \\
\text { cases C-279/96 - C-281/96, } \\
\text { EU:C:1998:403 }\end{array}$ & $\begin{array}{l}\text { Articles } 10 \text { and } 12 \text { of } \\
\text { Directive } 69 / 335 / \mathrm{EEC}\end{array}$ & $\begin{array}{l}\text { Harmonization of indirect } \\
\text { taxes }\end{array}$ \\
\hline $\begin{array}{l}\text { Judgment of } 22 \text { October } 1998, \\
\text { IN.CO.GE.'90, joined cases C-10/97 } \\
\text { to C-22/97, EU:C:1998:498 }\end{array}$ & $\begin{array}{l}\text { Article } 10 \text { of Directive } \\
69 / 335 / \mathrm{EEC}\end{array}$ & $\begin{array}{l}\text { Harmonization of indirect } \\
\text { taxes }\end{array}$ \\
\hline $\begin{array}{l}\text { Judgment of } 17 \text { November 1998, } \\
\text { Aprile, C-228/96, EU:C:1998:544 }\end{array}$ & $\begin{array}{l}\text { Articles } 9 \text { and } 12 \text { EEC (now } \\
28 \text { and } 30 \text { TFEU) }\end{array}$ & Customs union \\
\hline $\begin{array}{l}\text { Judgment of } 9 \text { February 1999, } \\
\text { Dilexport, C-343/96, EU:C:1999:59 }\end{array}$ & $\begin{array}{l}\text { Article } 95 \text { EEC (now } 110 \\
\text { TFEU) }\end{array}$ & $\begin{array}{l}\text { Non-discrimination in } \\
\text { taxes }\end{array}$ \\
\hline $\begin{array}{l}\text { Judgment of } 21 \text { September } 2000 \text {, } \\
\text { Michaïlidis, joined cases C-441/98 } \\
\text { and C-442/98, EU:C:2000:479 }\end{array}$ & $\begin{array}{l}\text { Articles } 9 \text { and } 12 \text { EEC (now } \\
28 \text { and } 30 \text { TFEU) }\end{array}$ & Customs union \\
\hline $\begin{array}{l}\text { Judgment of } 26 \text { September } 2000 \text {, } \\
\text { IGI, C-134/99, EU:C:2000:503 }\end{array}$ & Directive 69/335/EEC & $\begin{array}{l}\text { Harmonization of indirect } \\
\text { taxes }\end{array}$ \\
\hline $\begin{array}{l}\text { Judgment of } 8 \text { March 2001, } \\
\text { Metallgesellschaft, joined } \\
\text { cases C-397/98 and C-410/98, } \\
\text { EU:C:2001:134 }\end{array}$ & $\begin{array}{l}\text { Articles } 52 \text { and } 58 \text { EEC } \\
\text { (now } 49 \text { and } 54 \text { TFEU) }\end{array}$ & Right of establishment \\
\hline
\end{tabular}




\begin{tabular}{|c|c|c|}
\hline Case no. and name & $\begin{array}{c}\text { Main EU law } \\
\text { provision breached }\end{array}$ & Policy area at stake \\
\hline $\begin{array}{l}\text { Judgment of } 2 \text { October } 2003 \text {, } \\
\text { Weber's Wine World, C-147/01, } \\
\text { EU:C:2003:533 }\end{array}$ & $\begin{array}{l}\text { Article } 3(2) \text { of Directive } \\
92 / 12 / \mathrm{EEC}\end{array}$ & $\begin{array}{l}\text { Harmonization of excise } \\
\text { duties }\end{array}$ \\
\hline $\begin{array}{l}\text { Judgment of } 17 \text { June 2004, Recheio, } \\
\text { C-30/02, EU:C:2004:373 }\end{array}$ & $\begin{array}{l}\text { Article } 12 \text { of Directive } \\
\text { 69/335/EEC }\end{array}$ & $\begin{array}{l}\text { Harmonization of indirect } \\
\text { taxes }\end{array}$ \\
\hline $\begin{array}{l}\text { Judgment of } 12 \text { December } \\
\text { 2006, Test Claimants in the FII } \\
\text { Group Litigation, C- } 446 / 04 \text {, } \\
\text { EU:C:2006:774 }\end{array}$ & $\begin{array}{l}\text { Articles } 43 \mathrm{EC} \text { and } 56 \mathrm{EC} \\
\text { (now Articles } 49 \text { and } 63 \\
\text { TFEU) }\end{array}$ & $\begin{array}{l}\text { Right of establishment and } \\
\text { free movement of capital }\end{array}$ \\
\hline $\begin{array}{l}\text { Judgment of } 13 \text { March } 2007 \text {, } \\
\text { Test Claimants in the Thin Cap } \\
\text { Group Litigation, C-524/04, } \\
\text { EU:C:2007:161 }\end{array}$ & $\begin{array}{l}\text { Articles } 43,49 \text { and } 56-58 \\
\text { EC (now 49, } 56 \text { and 63-65 } \\
\text { TFEU) }\end{array}$ & $\begin{array}{l}\text { Right of establishment, } \\
\text { freedom to provide services } \\
\text { and free movement of } \\
\text { capital }\end{array}$ \\
\hline $\begin{array}{l}\text { Judgment of } 15 \text { March 2007, } \\
\text { Reemtsma, C-35/05, EU:C:2007:167 }\end{array}$ & $\begin{array}{l}\text { Article } 9 \text { of Directive } \\
\text { 77/388/EEC (Sixth VAT } \\
\text { Dir) }\end{array}$ & Common system of VAT \\
\hline $\begin{array}{l}\text { Judgment of } 10 \text { April 2008, } \\
\text { Marks \& Spencer, C-309/06, } \\
\text { EU:C:2008:211 }\end{array}$ & Principle of fiscal neutrality & Common system of VAT \\
\hline $\begin{array}{l}\text { Judgment of } 28 \text { January } 2010 \text {, } \\
\text { Direct Parcel Distribution, } \\
\text { C-264/08, EU:C:2010:43 }\end{array}$ & $\begin{array}{l}\text { Article } 221 \text { of Regulation } \\
\text { No } 2913 / 92\end{array}$ & Customs union \\
\hline $\begin{array}{l}\text { Judgment of } 6 \text { September } \\
\text { 2011, Lady \& Kid, C-398/09, } \\
\text { EU:C:2011:540 }\end{array}$ & $\begin{array}{l}\text { Article } 33 \text { of Directive } \\
\text { 77/388/EEC (Sixth VAT } \\
\text { Dir) }\end{array}$ & Common system of VAT \\
\hline $\begin{array}{l}\text { Judgment of } 15 \text { September 2011, } \\
\text { Accor, C-310/09, EU:C:2011:581 }\end{array}$ & $\begin{array}{l}\text { Articles } 43 \text { and } 56 \text { EC (now } \\
49 \text { and } 63 \text { TFEU) }\end{array}$ & $\begin{array}{l}\text { Freedom of establishment } \\
\text { and free movement of } \\
\text { capital }\end{array}$ \\
\hline $\begin{array}{l}\text { Judgment of } 20 \text { October 2011, } \\
\text { Danfoss, C-94/10, EU:C:2011:674 }\end{array}$ & $\begin{array}{l}\text { Article 3(2) of Directive } \\
92 / 12 / \mathrm{EEC}\end{array}$ & $\begin{array}{l}\text { Harmonization of excise } \\
\text { duties }\end{array}$ \\
\hline $\begin{array}{l}\text { Judgment of } 15 \text { December 2011, } \\
\text { Banca Antoniana, C-427/10, } \\
\text { EU:C:2011:844 }\end{array}$ & $\begin{array}{l}\text { Directive 77/388/EEC } \\
\text { (Sixth VAT Dir) }\end{array}$ & Common system of VAT \\
\hline $\begin{array}{l}\text { Judgment of } 19 \text { July 2012, } \\
\text { Littlewoods Retail, C-591/10, } \\
\text { EU:C:2012:478 }\end{array}$ & $\begin{array}{l}\text { Directive 77/388/EEC } \\
\text { (Sixth VAT Dir) }\end{array}$ & Common system of VAT \\
\hline $\begin{array}{l}\text { Judgment of } 16 \text { May 2013, Alakor, } \\
\text { C-191/12, EU:C:2013:315 }\end{array}$ & $\begin{array}{l}\text { Article } 17 \text { of Directive } \\
\text { 77/388/EEC (Sixth VAT } \\
\text { Dir) }\end{array}$ & Common system of VAT \\
\hline $\begin{array}{l}\text { Judgment of } 15 \text { October 2014, } \\
\text { Nicula, C-331/13, EU:C:2014:2285 }\end{array}$ & Article 110 TFEU & $\begin{array}{l}\text { Non-discrimination in } \\
\text { taxes }\end{array}$ \\
\hline $\begin{array}{l}\text { Judgment of } 24 \text { November } 2016 \text {, } \\
\text { SECIL, C-464/14, EU:C:2016:896 }\end{array}$ & Article 63 TFEU & Free movement of capital \\
\hline
\end{tabular}


It is often only with some difficulty that the policy area at stake and/ or the substantive EU rule breached can be identified, as the Court has focused more generally on the interface between national remedies and EU law principles of effective judicial protection. The case law nonetheless seems centered around a few specific issues but does expand to others. The first cases often concerned lingering subsidies to domestic food production, or import health inspection fees. Since the 1990s focus has turned to taxes, often excise duties or VAT. In recent cases the distribution of dividends, taxation and the free movement of capital seems to be an emerging theme. Now and then, however, less typical themes have popped up, notably non-discrimination of persons and the rules on competition.

On closer scrutiny of the argumentation of the Court of Justice in the case law there seems to have been a development in the Court's own view of the substantive scope of the repayment remedy. In San Giorgio the Court held that the right to repayment was a consequence and adjunct to "the rights conferred on individuals by the Community provisions prohibiting charges having an effect equivalent to customs duties or, as the case may be, the discriminatory application of internal taxes", indicating that the restitutionary remedy applied in those specific two fields of EU policy (which are not easily separated in practice). This limitation was soon abandoned, however, and in e.g. Barra the Court held instead that "the right to repayment of amounts charged by a Member State in breach of the rules of Community law is the consequence and complement of the rights conferred on individuals by the Community provisions as interpreted by the Court" ${ }^{45}$ This context-neutral phrase has been used since then, for instance in cases such as Comateb and Fantask. ${ }^{46}$

In the absence of any discernable exclusiveness I would submit that the right to repayment of charges levied in breach of internal market law should not be understood as specific to one or a few sectors of substantive EU law, but rather as indicative of a more general right to restitution from a Member State notwithstanding the policy field concerned.

In the next section focus will be on examining in more detail what the precise criteria seem to be for a Member State to be liable to repay a sum unduly levied.

\footnotetext{
${ }^{45}$ Judgment of 2 February 1988, Barra, 309/85, EU:C:1988:42, paragraph 17.

${ }^{46}$ See note 36 for full references.
} 


\section{Criteria for restitutionary liability of a Member State}

\section{a. Extracting criteria from the case law}

With regard to the identification of criteria for restitutionary liability as such, the first question must be to what extent the Court should at all intervene into the criteria set by national law for the purposes of restitution from the Member State? As stressed above, the Court of Justice has traditionally presupposed that the existing remedies in the Member States should suffice for the effective judicial protection of EU law rights. However, in situations where the Court has identified a specific remedy which must, as a matter of EU law, be available to claimants, this can serve as a starting point for piecemeal case law harmonization of that remedy. ${ }^{47}$ As described in section 3.a, such a starting point in respect of restitution from Member States came in Pigs and Bacon. Nonetheless the case law has to a very large extent dealt with ancillary issues, such as national timelimits for the bringing of the action, ${ }^{48}$ while the Court seems to have been less inclined to create uniform criteria for the remedy as such. By and large the Court has settled for scrutiny of national conditions for the exercise of the restitutionary remedy, using its effective judicial protection tool box.

The scarcity of guidance from the Court of Justice on the precise criteria for restitutionary liability can be read as revealing a non-interventionist approach. Alternatively, it could be read as indicating that the Court shares the view that repayments are no-brainers and that it is unnecessary to fix uniform criteria as it has done for the purposes of the Francovich damages action. To some extent such interpretations seem compatible with the case law insofar as the Court has offered no systematic reasoning on the applicable criteria for restitutionary liability that can be compared to the very explicit reasoning (and discussion) of the damages criteria in Francovich, Brasserie de Pêcheur and Dillenkofer. ${ }^{49}$ To this author it does seem that the

\footnotetext{
${ }^{47}$ As for instance with the action for damages from a Member State for a breach of EU law. In the case of competition damages the initiative of the Court in Judgment of 20 September 2001, Courage v Crehan, C-453/99, EU:C:2001:465 was picked up by the EU legislature, resulting in partial harmonization of the damages remedy through Directive 2014/104.

${ }^{48}$ See e.g. Judgment of 17 July 1997, Haahr Petroleum, C-90/94, EU:C:1997:368, paragraph 50; Judgment of 17 July 1997, Texaco, joined cases C-114/95 and C-115/95, EU:C:1997:371, paragraph 46; Judgment of 2 December 1997, Fantask, C-188/95, EU:C:1997:580, paragraph 48; Judgment of 17 June 2004, Recheio, C-30/02, EU:C:2004:373, paragraphs 20-25; and Judgment of 15 December 2011, Banca Antoniana, C-427/10, EU:C:2011:844, paragraph 32.

${ }^{49}$ For full case references see notes 1 and 22 .
} 
Court has been happy to settle for a lenient approach as long as national criteria do not run contrary to the principle of effectiveness. Nevertheless it is maintained that certain criteria are in fact discernable from the case law.

In section 3.a there was a quote from Pigs and Bacon. The Court stipulated that where a trader has been "required [implicitly: by a Member State] to pay [a] levy (...) which [was] devoted to purposes incompatible with Community [now: EU] law", the trader has a right to claim reimbursement. ${ }^{50}$ From this holding we can distinguish some preliminary criteria: The claimant has been required to pay a charge, the requirement was imposed by the Member State, and the purpose of the charge was incompatible with EU law. It has also been noted that the Court held in San Giorgio and many subsequent cases that the "entitlement to the repayment of charges levied by a Member State contrary to the rules of [EU] law is a consequence of, and an adjunct to, the rights conferred on individuals by the [EU] provisions" prohibiting such charges. ${ }^{51}$ This holding revises the criteria somewhat by stressing that the claimant holds a right under EU law which is frustrated by the levy at issue. It also seems to require a more evident breach of EU law. In Pigs and Bacon it was sufficient that the purpose of the charge was incompatible with EU law. In San Giorgio the Court referred to the levy being prohibited under EU law. The possibly different implications of these holdings will be discussed below. Moreover, as mentioned in the introduction, the occurrence of parallel applicability of restitutionary and damages liability has prompted the Court to adopt a test to distinguish instances where the Member State can be held liable in restitution from instances where damages are the only viable option. ${ }^{52}$ This "inevitable consequence test" will also be discussed below.

Consequently it is submitted that the Court of Justice has in fact indicated a set of criteria for restitutionary liability of Member States under EU law, even if it has done so in an ad hoc manner and with less clarity and transparency than in damages liability. With some adaptation, the following criteria are suggested on the basis of the case law:

\footnotetext{
${ }^{50}$ Judgment of 26 June 1979, Pigs and Bacon, 177/78, EU:C:1979:164, paragraph 25.

${ }^{51}$ Judgment of 9 November 1983, San Giorgio, 199/82, EU:C:1983:318, paragraph 12. See also the other cases cited in note 36 .

${ }^{52}$ See note 10 and the accompanying text. That damages liability and restitutionary liability of Member States overlap and can apply in parallel has been indicated by the Court of Justice in e.g. Judgment of 14 January 1997, Comateb, joined cases C-192/95 - C-218/95, EU:C:1997:12, paragraph 34 .
} 
1. The existence of a substantive right conferred on the claimant by EU law,

2. The existence of a payment from the claimant, collected by or on behalf of the Member State,

3. The incompatibility of the basis of that payment with EU law, and

4. The payment following as an inevitable consequence of the breach of EU law by the Member State.

It is interesting to make a brief comparison of these criteria with those of liability in damages for Member States. ${ }^{53}$ The existence of a substantive right conferred on the claimant by EU law is shared by both sets of criteria. By contrast the second criterion above has no equivalent in the damages criteria. This is unsurprising as the second criterion essentially identifies the existence of an imbalance between the parties which the restitutionary remedy seeks to reverse, thus embodying the restitutionary nature of the claim. If there is an equivalent in damages then it is perhaps the criterion of harm incurred and to be compensated, which has usually been left implicit in EU case law on the Francovich remedy even though it arguably constitutes the essence of damages. ${ }^{54}$ The third criterion is a parallel to the "sufficiently serious breach" criterion in damages liability, but the bar is much lower: As will be discussed below, incompatibility with EU law seems to be sufficient in restitution. Finally, the inevitable consequence test parallels the causation criterion in damages, but is obviously more stringent than its damages law counterpart.

These criteria, extracted from the case law, will now be examined in turn.

\section{b. The criterion of a right}

To some extent it would seem self-evident that there must be a substantive right conferred on the claimant by EU law that has been frustrated by reason of the levying of the disputed charge. If there was no infringed right there would obviously be no need for a remedy ${ }^{55}$ However, the pur-

\footnotetext{
${ }^{53}$ On the criteria for damages liability see Judgment of 8 October 1996, Dillenkofer, joined cases C-178/94, C-179/94, C-188/94, C-189/94 and C-190/94, EU:C:1996:375. For legal writing see e.g. the literature cited in note 5 .

${ }^{54}$ Albeit with a few exceptions, most notably Judgment of 5 March 1996, Brasserie du Pêcheur, joined cases C-46/93 and C-48/93, EU:C:1996:79, paragraphs 81-87. For a statement of nonintervention unless called for with reference to the principles of equivalence and effectiveness see Judgment of 9 December 2010, Combinatie Spijker, C-568/08, EU:C:2010:751, paragraphs 88-90.

${ }^{55}$ Cf. the three-tier model developed by van Gerven, "Of Rights, Remedies and Procedures".
} 
pose of this criterion should rather be to highlight that the rule of EU law breached must be of such a character that it confers a right on the claimant. This criterion thus draws a line between different types of EU law rules and calls on the courts - and ultimately on the Court of Justice - to decide whether the rule breached by the Member State is of such a character that it does in fact confer a substantive right on the claimant. ${ }^{56}$ In this manner the existence of a substantive right, conferred on the claimant by EU law, is what "triggers" the applicability of the EU law principles of effective judicial protection in this context. ${ }^{57}$

It is possible here to make a cautious comparison to the German tort law concept of a Schutzgesetz, i.e. a reflection without prejudice to the precise meaning given to that concept in German law. ${ }^{58}$ The analysis of the EU law rule should similarly establish that the rule at issue has a protective purpose, in other words that it is designed to protect the interests of individuals such as the claimant. This does not, for the sake of clarity, exclude the possibility that the rule at issue also serves other purposes. For example, Article 110 TFEU is designed to "ensure the free movement of goods between Member States (...) by the elimination of all forms of protection which may result from the application of internal taxation that discriminates against products from other Member States" ${ }^{59}$ Hence this rule is designed to promote the same general economic interests that are pursued by the internal market system as a whole (e.g. consumer welfare and an efficient distribution of resources). ${ }^{60}$ Nevertheless it was established in Just that Article (now) 110 TFEU also confers a right on individuals in the Member States to be protected from discriminatory indirect taxation. ${ }^{61}$

\footnotetext{
${ }^{56}$ It must of course also be established that it is that specific right which has been frustrated by the levying of the disputed charge, but the latter analysis belongs to the fourth criterion identified above.

${ }^{57}$ This is admittedly a twisted reference to Michael Dougan's "trigger theory" as Dougan does not share the view that a right triggers EU law before national courts. Instead his view is that the criteria for direct effect do, see e.g. Michael Dougan, "When Worlds Collide! Competing Visions of the Relationship between Direct Effect and Supremacy", Common Market Law Review 44, no. 4 (2007): 931.

${ }^{58}$ Cf. Sacha Prechal, Directives in EC Law, Oxford EC Law Library (Oxford: Oxford University Press, 2006), 284-285 on the concept of a right in the Francovich remedy.

${ }^{59}$ Judgment of 3 March 1988, Bergandi, 252/86, EU:C:1988:112, paragraph 24.

${ }^{60}$ For a brief introduction to EU free trade policies (with references), see Catherine Barnard, The Substantive Law of the EU: The Four Freedoms (Oxford: Oxford University Press, 2016), 4-8.

${ }^{61}$ Judgment of 27 February 1980, Just, 68/79, EU:C:1980:57, paragraphs 25-27.
} 
These purposes complement each other, as the "vigilance of individuals"62 will help promote the policies pursued by the EU Treaties.

The power to ultimately establish whether a rule of EU law has such a protective purpose falls within the interpretive competence of the Court of Justice under Article 267 TFEU. Consequently the application of this criterion of a right is governed by EU law.

\section{c. The payment criterion - subdividing into impoverishment and enrichment?}

Most of the repayment case law of the Court of Justice indicates no more than a criterion of a payment made by the claimant which the restitutionary remedy seeks to reverse. If there was no such payment then there is nothing to reverse, and the action brought by the claimant would fail. The payment criterion also serves to distinguish actions for repayment of sums not due from actions for payment of sums due but not paid. ${ }^{63}$

The case law of the Court of Justice nevertheless includes Reemtsma and Danfoss,${ }^{64}$ two cases which involve three-party situations and which are therefore not quite so simple. Indeed they are very difficult to reconcile with other case law for the purposes of finding workable criteria for restitutionary liability. In both Reemtsma and Danfoss the payment at issue was not made directly to any institution or agency of the Member State but to a third party, but the circumstances were not identical. In Reemstma a provider of services (the third party, C) had mistakenly charged and collected VAT from the claimant (B) and paid the sum to the Member State (A). When the mistake was revealed $\mathrm{C}$ had become insolvent, leaving $\mathrm{B}$ with no other option than an action against A. In Danfoss the Member State (A) had charged an excise duty, in breach of EU law, from the third party (C) who passed it on to the claimant (B). The duty was designed to be passed on, and circumstances seem to have been such that they were indeed passed on in their entirety without $C$ suffering any decrease in sales. Consequently $\mathrm{C}$ had no incentive to claim reimbursement from $\mathrm{A}$ and did

\footnotetext{
${ }^{62}$ Judgment of 5 February 1963, van Gend \& Loos, 26/62, EU:C:1963:1, 13.

${ }^{63}$ Such actions for payments due (pursuant to EU law) but not paid (by reason of conflicting national law) were brought in e.g. Judgment of 22 April 1997, Sutton, C-66/95, EU:C:1997:207; and Judgment of 13 March 1991, Cotter and McDermott, C-377/89, EU:C:1991:116. Cf. also the reference to sums "withheld by" a Member State in Judgment of 12 December 2006, Test Claimants in the FII Group Litigation, C-446/04, EU:C:2006:774, paragraph 207.

${ }^{64}$ Judgment of 15 March 2007, Reemtsma, C-35/05, EU:C:2007:167; and Judgment of 20 October 2011, Danfoss, C-94/10, EU:C:2011:674.
} 
not do so. As in Reemtsma, the issue in Danfoss was therefore whether B could reclaim from A directly? ${ }^{65}$ In both cases the Court of Justice held that if $B$ were able to obtain relief from $C$, then it would be compatible with EU law for A to refuse reimbursement to B. By contrast, the Court continued, if it was virtually impossible or excessively difficult for B to obtain reimbursement from $\mathrm{C}$, then A could not oppose a claim from B. ${ }^{66}$

As mentioned the situations in the two cases are not quite the same, and if analysed from a private law perspective the difference becomes clear. The circumstances in Reemstma are arguably reminiscent of the Roman actio de in rem verso, still available in many European jurisdictions, ${ }^{67}$ as the enrichment of the Member State arises as a consequence of an error by C. Under the actio de in rem verso there is no fault of any kind on behalf of A (here the Member State, in Rome the paterfamilias) and if possible B should seek compensation from $C$. However, to the extent that the dealings of $B$ and $C$ have led to an enrichment of $A$, there is a subsidiary restitutionary liability for A against B. In Danfoss the situation is different, as the error was made by A. The measure which was incompatible with EU law had been taken by the Member State, and the direct taxpayer (C) was only passing-on the economic burden caused by that error to B. In such situations the Court of Justice has clearly indicated that $\mathrm{B}$ must be able to find reimbursement from either A or C. If it is virtually impossible or

\footnotetext{
${ }^{65}$ In this section these cases are examined in order to explain why it is necessary to subdivide the issue of payment into criteria of impoverishment of the claimant and enrichment of the Member State. Obviously they also raise issues on the proper understanding of "inevitable consequence", to be discussed in the section devoted to that test.

${ }^{66}$ Judgment of 15 March 2007, Reemtsma, C-35/05, EU:C:2007:167, paragraphs 39-42; Judgment of 20 October 2011, Danfoss, C-94/10, EU:C:2011:674, paragraphs 26-29. For a closer analysis of these holdings see Magnus Strand, The Passing-On Problem..., paragraphs 2.059-2.060 (on the unorthodox use of the principle of effectiveness to overcome difficulties caused by factual circumstances) and paragraphs 5.028-5.050 (on "leapfrogging" and particular issues relating e.g. to the word "oppose" in Danfoss).

${ }^{67}$ For history of the actio de in rem verso see Reinhard Zimmermann, The Law of Obligations, 878-884. On this action in French law see Rebecca Williams, Unjust Enrichment and Public Law: A Comparative Study of England, France and the UK (Oxford: Hart Publishing, 2011), 172-174. In Sweden, the actio de in rem verso in statutory form has been available since the 1734 Code (Handelsbalken) 18 kap 3 §. A modern example in Swedish law is Miljöbalken (1998:808) 10 kap 9 $\$$, under which the owner of contaminated real estate property, notwithstanding having purchased the property in good faith and with no knowledge of the contamination, has a subsidiary liability to contribute to costs for its sanitation to the extent that such sanitation increases the value of the property.
} 
excessively difficult to obtain repayment from $\mathrm{C}$, then $\mathrm{B}$ must be allowed to claim from $\mathrm{A} .{ }^{68}$ If $\mathrm{B}$ has been repaid by $\mathrm{C}$, then $\mathrm{C}$ can reclaim from $\mathrm{A} .{ }^{69}$

For the purposes of this presentation the crucial point is that it follows from Reemtsma and Danfoss that restitutionary liability for a Member State does not require that a payment was made directly to an institution or agency of that Member State. This calls the payment criterion into question. There seem to be two options: Under the first option it is sufficient for restitutionary liability of the Member State that a payment was made, irrespective of to whom it was made and irrespective of whether that payment is finally collected by the Member State. Under the second option the payment criterion is subdivided into two criteria commonly used in private law restitution by reason of unjust enrichment, namely a criterion of impoverishment on behalf of the claimant and enrichment on behalf of the Member State..$^{70}$ For example, what if, in Reemtsma, C had become insolvent before paying the VAT collected from B to A? Would B have had no recourse against $A$, since $A$ had not been enriched $?^{71}$ Another example: Assume that national law in a Member State required companies receiving goods carried by sea to make payments to a privately owned and managed fund for the preservation of maritime resources. To the extent that such a requirement is not justifiable under Article 36 TFEU it would be contrary to EU law. Without discussing the vexed issue of attempting a horizontal claim against the fund, ${ }^{72}$ should the companies be able to use a restitutionary claim against the Member State?

This has not been addressed by the Court of Justice. It can be noticed that in every case known to this author it has been beyond question that the Member State has been enriched, since the disputed payment has always found its way, directly or indirectly, to the public purse. And yet the reasoning of the Court in Reemtsma focuses entirely on neutralizing

\footnotetext{
${ }^{68}$ Judgment of 20 October 2011, Danfoss, C-94/10, EU:C:2011:674, paragraphs 27-28.

${ }^{69}$ Judgment of 14 January 1997, Comateb, joined cases C-192/95 - C-218/95, EU:C:1997:12, paragraph 24.

${ }^{70}$ See e.g. Draft Common Frame of Reference, Article VII. - 1:101. Cf. also Judgment of 16 December 2008, Masdar, C-47/07 P, EU:C:2008:726, paragraph 49 where the criteria for unjust enrichment liability of EU institutions (including enrichment of the $\mathrm{EU}$ and impoverishment of the claimant) were established by the Court of Justice.

${ }^{71}$ Cf. the discussion in Opinion of AG Sharpston of 8 June 2006, Reemtsma, C-35/05, EU:C:2006:377, paragraph 90 .

${ }^{72}$ On plausible horizontal restitutionary liability for a breach of EU law, see Magnus Strand, The Passing-On Problem, paragraphs 8.033-8.040.
} 
the burden placed on the claimant by reason of the erroneously invoiced VAT. ${ }^{73}$ Similarly, in Danfoss, the Court of Justice explained that "the right to the recovery of sums unduly paid helps to offset the consequences of the duty's incompatibility with EU law by neutralising the economic burden which that duty has unduly imposed on the operator who, in the final analysis, has actually borne it". ${ }^{74}$ No underlying policy of disgorgement of the unjust enrichment of the Member State was mentioned.

Another issue not clearly addressed by the Court is whether the impoverishment of the claimant in some other way than through a payment could suffice to give rise to restitutionary liability for the Member State, although there are some indications in that direction. In FII, for instance, the claim was (partially) for restitution by reason of waivers of tax relief, allegedly prompted by an infringement of EU law by the Member State. ${ }^{75}$ The Court however dismissed the action without analysing whether such an impoverishment could be remedied in restitution under EU law. One might also imagine situations where a claimant has not been compelled to pay a charge but to perform free services in the public interest, or the like, in order to gain access to provide services on a national market; a requirement that could run contrary to Article 49 TFEU. The concept of a "payment" might therefore prove too narrow in future case law, but the Court of Justice has not yet clarified whether it can be broadened.

A simple payment criterion, on the one hand, and a set of two criteria of impoverishment of the claimant and enrichment of the Member State, on the other hand, both have strengths and weaknesses. The strengths of the simple payment criterion are that it is less complicated to prove and that it does not open up for new possibilities of defences for Member States, e.g. change of position. ${ }^{76}$ Its weaknesses are that it makes it more difficult to explain the Court's case law on the defence of passing-on (for if enrichment of the Member State is irrelevant, then impoverishment or disimpoverishment of the claimant should be equally irrelevant), ${ }^{77}$ and that it makes

\footnotetext{
${ }^{73}$ Judgment of 15 March 2007, Reemtsma, C-35/05, EU:C:2007:167, paragraphs 38-42.

${ }^{74}$ Judgment of 20 October 2011, Danfoss, C-94/10, EU:C:2011:674, paragraph 23.

${ }^{75}$ Judgment of 12 December 2006, Test Claimants in the FII Group Litigation, C-446/04, EU:C:2006:774. See further section 4.e.

${ }^{76}$ On change of position (disenrichment) in English law see e.g. Rebecca Williams, Unjust Enrichment and Public Law, 136-149. In Swedish law the defence of change of position is available to the fiscal authority, see Supreme Court judgment NJA 2016 s 1074.

${ }^{77}$ Cf. Rebecca Williams, Unjust Enrichment and Public Law, 175-176 where it is noted that under the French action of répétition de l'indu the claimant does not need to prove enrichment of the
} 
the action less open to new developments in less clear-cut cases. Another weakness is that a focus on the payment (constituting impoverishment of the claimant) risks compromising the restitutionary character of the action by coming very close to being a compensatory action - a space already occupied in EU law by the Francovich remedy. The strengths of using criteria of impoverishment and enrichment are, conversely, that they could offer better systematic explanations for the details of restitutionary liability and be more flexible ${ }^{78}$ but also that they would better reflect the realities of European private law and be better aligned with the criteria for unjust enrichment liability of the EU institutions. ${ }^{79}$ Their weaknesses are that evidence of enrichment of the Member State would be required and, as mentioned, that a criterion of such enrichment does not seem easily compatible with the reasoning of the Court of Justice in Reemtsma and Danfoss.

Both options also seem to remain open to the Court of Justice. Perhaps therefore the better view is that although the Court has remained content with the simple payment criterion, it should keep a window of opportunity for development into impoverishment and enrichment criteria if they become necessary. Therefore, to summarise, the case law (as it stands) seems to indicate that it is a criterion for restitutionary liability of the Member State that a payment collected by or on behalf of the Member State was made by the claimant, irrespective of to whom it was made. Possibly this criterion is also satisfied irrespective of whether that payment has finally been collected by the Member State, but the case law is inconclusive on that point. Possibly this criterion is also satisfied if the claimant has been impoverished in another manner than through a payment.

In connection with the payment criterion it should finally be highlighted that the payment (or, more often than not, the series of payments) also serves as a yardstick for the estimation of the award of repayment. The principal sum to be repaid should, as a point of departure, correspond to the sum paid but not due. The Court of Justice has also settled that

\footnotetext{
defendant or impoverishment of her-/himself, and as a consequence passing-on (répercussion) is irrelevant. On the term "disimpoverishment" as a description of passing-on see Michael Rush, The Defence of Passing On (Oxford: Hart Publishing, 2006), 11-17 and Peter Birks, Unjust Enrichment, Clarendon Law Series (Oxford: Oxford University Press, 2005), 219-221.

${ }^{78}$ They could serve to encompass e.g. situations where sums due (pursuant to EU law) but not paid (by reason of national law) as they can likewise be described as impoverishments of the claimant and enrichments of the Member State; cf. note 63 and the accompanying text.

${ }^{79}$ See Judgment of 16 December 2008, Masdar, C-47/07 P, EU:C:2008:726, paragraph 49.
} 
interest is payable on the principal sum. ${ }^{80}$ There are however other factors that may increase or decrease the sum to be repaid, such as the passing-on of the burden of the unlawful charge. These matters will not be examined in detail here. ${ }^{81}$

The identification of a payment does not seem to trigger any need for interpretation of EU law but simply an assessment of the evidence presented to the national court. It should therefore be quite safe to entrust the national courts with the application of this criterion. Of course, national conditions such as limitations on admissible evidence or the like will be subject to scrutiny under the EU law principles of equivalence and effectiveness.

\section{d. The incompatibility criterion}

The third criterion extracted from the case law was that the basis for the levy, such as a national administrative decision to charge importers an inspection fee of some kind, is incompatible with EU law. As the basis of the payment is thus unlawful, the payment will - in the language of the law of restitution - lack valid justification. ${ }^{82}$ Under such circumstances it should be reversed.

It was mentioned above that the Court has not been quite consistent concerning the character of the breach of EU law which is necessary to satisfy this criterion. Obviously a "sufficiently serious breach" is not necessary, but is it nonetheless crucial that the Member State has violated a clear prohibition? Taking this a step further, is it for instance necessary that the rule

\footnotetext{
${ }^{80}$ Judgment of 19 July 2012, Littlewoods Retail, C-591/10, EU:C:2012:478, paragraph 26.

${ }^{81}$ On the defence of passing-on in this context see Magnus Strand, The Passing-On Problem..., paragraphs 5.074 - 5.163. On other increases and decreases, see Ibid., paragraphs $5.065-5.069$. The case law on estimating the restitutionary award has been summarised in an "adequate indemnity test" by Maximilian Schlote, "The San Giorgio 'Cause of Action", British Tax Review 2014, no. 2 (2014): 109-112. On how restitutionary awards can be estimated in European private law see Draft Common Frame of Reference, Book VII, ch. 5.

${ }^{82}$ Private lawyers will recognise that, in this statement, I am subscribing to the continental European private law view of unjust(ified) enrichment as an enrichment sine causa. The same result could however be reached with common law reasoning, since it has been established in Woolwich Equitable Building Society v Inland Revenue Commissioners [1993] AC 70 that unlawfulness of a payment made to a public authority (i.e. that the basis for such a payment has been ultra vires, such as when it was incompatible with EU law) is an "unjust factor" that triggers restitutionary liability for the Inland Revenue.
} 
breached is clear, precise and unconditional - i.e., that the rule breached has direct effect between the claimant and the Member State?83

As is well-known, the concept of direct effect remains controversial and that is perhaps as good a reason as any other to avoid adopting it as a subcriterion here ${ }^{84}$ More importantly such a requirement of direct effect finds no support in the case law, not even implicit support. As mentioned above the Court was content in Pigs and Bacon to find that the purpose of the charge levied was incompatible with EU law. ${ }^{85}$ More recently, in Marks \& Spencer, the United Kingdom was held liable to repay taxes that were incompatible with the general principle of fiscal neutrality. ${ }^{86}$ As a general principle of EU law cannot of itself satisfy the criteria for direct effect, Marks \& Spencer militates against the view that direct effect should be a sub-criterion here.

The identification of a specific prohibition against the levy at issue has nonetheless floated in and out of the Court's reasoning. In San Giorgio and much subsequent case law the Court seemed to restrict the scope of restitutionary liability to instances where the levy was prohibited by a provision of EU law. ${ }^{87}$ In Barra, however, a more lenient phrase was used, as the Court stressed instead "the rights conferred on individuals by the Community provisions as interpreted by the Court". ${ }^{88}$ This phrase was picked up again in BP Soupergaz and in Fantask, ${ }^{89}$ and in the majority of case law following after Fantask this more lenient phrase has been used. ${ }^{90}$

${ }^{83}$ This view seems to have been supported by in the Opinion of AG Cruz Villalón of 7 December 2010, Lady \& Kid, C-398/09, EU:C:2010:744, paragraph 22.

${ }^{84}$ Influential contributions to the debate over the concept of direct effect of EU law include Dougan, "When worlds collide!...”; Koen Lenaerts and Tim Corthaut, "Of Birds and Hedges: The Role of Primacy in Invoking Norms of EU Law", European Law Review 31, no. 3 (2006); and Bruno de Witte, "Direct Effect, Primacy, and the Nature of the Legal Order", in The Evolution of EU Law, ed. Paul Craig and Gráinne de Búrca (Oxford: Oxford University Press, 2011).

${ }^{85}$ Judgment of 26 June 1979, Pigs and Bacon, 177/78, EU:C:1979:164, paragraph 25.

${ }^{86}$ Judgment of 10 April 2008, Marks \& Spencer, C-309/06, EU:C:2008:211, paragraphs 32-36.

${ }^{87}$ Judgment of 9 November 1983, San Giorgio, 199/82, EU:C:1983:318, paragraph 12; Judgment of 14 January 1997, Comateb, joined cases C-192/95 - C-218/95, EU:C:1997:12, paragraph 20; Judgment of 17 July 1997, Texaco, joined cases C-114/95 and C-115/95, EU:C:1997:371, paragraph 40; Judgment of 17 July 1997, GT-Link, C-242/95, EU:C:1997:376, paragraph 58.

${ }^{88}$ Judgment of 2 February 1988, Barra, 309/85, EU:C:1988:42, paragraph 17.

${ }^{89}$ Judgment of 6 July 1995, BP Soupergaz, C-62/93, EU:C:1995:223, paragraph 40; Judgment of 2 December 1997, Fantask, C-188/95, EU:C:1997:580, paragraph 38.

${ }^{90}$ Judgment of the Court of 22 October 1998, IN.CO.GE.'90, joined cases C-10/97 to C-22/97, EU:C:1998:498, paragraph 24; Judgment of 26 September 2000, IGI, C-134/99, EU:C:2000:503, paragraph 34; Judgment of 8 March 2001, Metallgesellschaft, joined cases C-397/98 and C-410/98, 
In Michailidis, Lady \& Kid and Danfoss, however, the San Giorgio holding has appeared. ${ }^{91}$ There is no apparent explanation for the difference, but in Dilexport the Court made a distinction that could serve to explain:

It should be borne in mind that, according to settled case-law of the Court, the right to a refund of charges levied in a Member State in breach of rules of Community law is the complement of the rights conferred on individuals by the Community provisions prohibiting charges having an effect equivalent to customs duties or, as the case may be, the discriminatory application of domestic charges, as interpreted by the Court of Justice...92

This holding implies that the San Giorgio phrase would apply when the Member State has levied charges that have an effect equivalent to customs duties, while the Barra phrase would apply in other cases (notably breaches of Article 110 TFEU). As promising as such a distinction would seem, it does not hold water as it simply does not reflect the case law. The San Giorgio phrase has been used in Article 110 TFEU cases, ${ }^{93}$ and the Barra phrase has been used in customs union cases. ${ }^{94}$ Moreover, the Court has cross-cited case law using both phrases with no trace of distinction. ${ }^{95}$

By reason of these assessments it is submitted that the distinction between the two phrases cannot be significant. As a consequence, it cannot be maintained within any field of EU policy that a specific prohibition against the charge levied must be identified in order for the charge to be repayable. The infringement of the claimant's rights through a levy must suffice. The situation in Reemtsma may serve to illustrate, as the "fault" attributable to the Member State in that case was slight indeed. VAT had been levied by reason of an error by a supplier, who had paid the VAT

EU:C:2001:134, paragraph 84; Judgment of 12 December 2006, Test Claimants in the FII Group Litigation, C-446/04, EU:C:2006:774, paragraph 202; Judgment of 24 November 2016, SECIL, C-464/14, EU:C:2016:896, paragraph 164.

${ }^{91}$ Judgment of 21 September 2000, Michailidis, joined cases C-441/98 and C-442/98, EU:C:2000:479; Judgment of 6 September 2011, Lady \& Kid, C-398/09, EU:C:2011:540, paragraph 17; Judgment of 20 October 2011, Danfoss, C-94/10, EU:C:2011:674, paragraph 20.

${ }_{92}$ Judgment of 9 February 1999, Dilexport, C-343/96, EU:C:1999:59, paragraph 23.

${ }_{93}^{93}$ Judgment of 17 July 1997, Texaco, joined cases C-114/95 and C-115/95, EU:C:1997:371, paragraph 40; Judgment of 17 July 1997, GT-Link, C-242/95, EU:C:1997:376, paragraph 58.

${ }^{94}$ Judgment of 28 January 2010, Direct Parcel Distribution, C-264/08, EU:C:2010:43, paragraph 45.

${ }^{95}$ See e.g. Judgment of 15 September 2011, Accor, C-310/09, EU:C:2011:581, paragraph 71. 
to the Member State and then become insolvent. The national system for refunding VAT erroneously levied was based on the presumption that VAT could be repaid to suppliers who then repaid to their customers, but there was no mechanism to reimburse customers and uphold fiscal neutrality in VAT in this situation. The "breach" of EU law was thus that there was a lacuna in the system for refunds for this unforeseen kind of situation. The Court of Justice acknowledged that there were no EU rules on such details but only a general obligation for the Member States to "take all necessary measures to ensure that the taxable person neither benefits nor is prejudiced unjustifiably". ${ }^{96}$

It is thus concluded that no special characteristics of the EU law rule breached are needed. A parallel situation is found in case law on horizontal situations, where effective judicial protection of rights conferred on individuals is required independently of whether the rule at issue satisfies criteria such as those for direct effect, and can alternatively be attained by the national courts through the setting aside of national measures that are incompatible with EU law (so-called exclusionary effect). ${ }^{97}$ Similarly, in the situation discussed here, the criterion of incompatibility for (vertical) restitutionary liability of a Member State is met if the basis for the payment, collected by or on behalf of the Member State (even if collected in error), was incompatible with EU law.

As hinted, the decision of whether the collecting of a payment is incompatible with EU law necessarily entails interpretation of the EU law rule at issue, which falls within the interpretive competence of the Court of Justice under Article 267 TFEU. If the final decision also entails interpretation of a national legal provision, however, the latter falls under the jurisdiction of the national court. Consequently the application of this criterion is governed by EU law and, sometimes, national law in interaction with EU law.

\section{e. The inevitable consequence test}

The inevitable consequence test has emerged from situations where damages liability and restitutionary liability of the Member State may overlap.

\footnotetext{
${ }^{96}$ Sixth Council Directive 77/388/EEC of 17 May 1977 on the harmonization of the laws of the Member States relating to turnover taxes [1977] OJ L 145/1 Article 20(6), cited in Judgment of 15 March 2007, Reemtsma, C-35/05, EU:C:2007:167, paragraph 39.

${ }^{97}$ Cf. Judgment of 19 January 2010, Kücükdeveci, C-555/07, EU:C:2010:21, paragraph 51; and Judgment of 19 April 2016, Dansk Industri, C-441/14, EU:C:2016:278, paragraphs 35-37.
} 
It is settled case law that the two may apply in parallel, ${ }^{98}$ and as the damages option entails a need for evidence of e.g. a sufficiently serious breach of EU law and a direct causal link between that breach and the alleged harm incurred, some claimants have preferred to attempt a restitutionary action notwithstanding that the circumstances were not such that would typically be remedied through restitution. In the context of such attempts the question to be addressed by the Court of Justice has been whether national courts can deny access to the restitutionary remedy in accordance with the restrictions laid down in national law (in effect instructing the claimant to attempt the damages remedy instead). In other words, the issue has been whether EU law requires for restrictive traditional national concepts of restitution to be broadened in the interest of effective judicial protection of rights conferred on individuals by EU law.

In order to find a working delineation, the Court of Justice has held that the action for repayment of sums levied in breach of EU law will apply only where the alleged frustration of the claimant's rights is an "inevitable consequence" of the breach of EU law at issue. ${ }^{99}$ The background to that holding, as well as its legal significance, obviously deserves closer examination.

The inevitable consequence test is by no means a well-elaborated test carved out in consistent case law. To the contrary, this presentation is based on only two Court dicta, albeit dicta that have been picked up by Advocates General and that fit European private law tendencies quite well. The dicta at issue are from FII and Thin Cap. ${ }^{100}$ In FII a reference was made to the Court in the context of group litigation concerning so-called franked investment income (FII) in which the claimants had brought an action for recovery of certain tax amounts levied on dividends paid by companies resident in other Member States or in third countries. The claimants were all companies resident in the UK and part of the British American Tobacco Group. The rather complex technical issues under scrutiny revolved around the passing through of dividends from non-UK subsidiaries within the group to shareholders of UK resident parent companies.

\footnotetext{
${ }^{98}$ Judgment of 14 January 1997, Comateb, joined cases C-192/95 - C-218/95, EU:C:1997:12, paragraph 34.

${ }_{99}^{9}$ Judgment of 12 December 2006, Test Claimants in the FII Group Litigation, C-446/04, EU:C:2006:774, paragraph 207.

${ }^{100}$ Judgment of 12 December 2006, Test Claimants in the FII Group Litigation, C-446/04, EU:C:2006:774; and Judgment of 13 March 2007, Test Claimants in the Thin Cap Group Litigation, C-524/04, EU:C:2007:161.
} 
The Court of Justice, having found that a number of aspects of the UK system for group taxation were precluded by Articles 43 and $53 \mathrm{EC}^{101}$ on the freedom of establishment and the free movement of capital, respectively, was asked by the national court how to classify the actions brought by the claimants in order to remedy the losses sustained by them under the FII system. Specifically, the national court asked whether the actions were to be classified as claims for the repayment of charges levied in breach of EU law or as claims for damages from the Member State. ${ }^{102}$

The Court of Justice declined to assign a legal classification of the actions brought before the national court, holding that it was for the claimants to specify the nature and basis for their actions under the supervision of the national court. ${ }^{103}$ In doing so, the Court pointed out, the national court was obliged to observe the EU principles on effective judicial protection. ${ }^{104}$ With regard to certain heads of claim, however, the Court of Justice went further:

...neither the reliefs waived by a taxpayer in order to be able to offset in full a tax levied unlawfully (...) against an amount due in respect of another tax, nor the loss and damage suffered by resident companies (...) because they saw themselves as having to increase the amount of their dividends so as to compensate for the lack of a tax credit in the hands of their shareholders, can form the basis of an action under Community law for the reimbursement of the tax unlawfully levied or of sums paid to the Member State concerned or withheld by it directly against that tax. Such waivers of relief or increases in the amount of dividends are the result of decisions taken by those companies and do not constitute, on their part, an inevitable consequence of the refusal by the United Kingdom to grant those shareholders the same treatment as that afforded to shareholders receiving a distribution which has its origin in nationally-sourced dividends.

\footnotetext{
${ }^{101}$ Now Articles 49 and 63 TFEU.

102 Judgment of 12 December 2006, Test Claimants in the FII Group Litigation, C-446/04, EU:C:2006:774, paragraph 31.

${ }^{103}$ This holding followed precedence from Judgment of 8 March 2001, Metallgesellschaft, joined cases C-397/98 and C-410/98, EU:C:2001:134, paragraph 81. See also Judgment of 13 March 2007, Test Claimants in the Thin Cap Group Litigation, C-524/04, EU:C:2007:161, paragraph 109; and Judgment of 20 October 2011, Danfoss, C-94/10, EU:C:2011:674, paragraph 32.

${ }^{104}$ Judgment of 12 December 2006, Test Claimants in the FII Group Litigation, C-446/04, EU:C:2006:774, paragraphs 201-204. Cf. the Opinion of AG Geelhoed of 6 April 2006, EU:C:2006:240, paragraph 134
} 
That being the case, it is for the national court to determine whether the waivers of relief or the increases in the amount of dividends constitute, on the part of the companies concerned, financial losses suffered by reason of a breach of Community law for which the Member State in question is responsible. ${ }^{105}$

In essence, the reasoning of the Court was repeated in Thin Cap, ${ }^{106}$ another case arising from the UK international taxation system. Thus, pursuant to these cases, it seems that the restitutionary action will apply only where the payment made (or, possibly, other impoverishments of the claimant indicated in the quote) is an "inevitable consequence" of the breach at issue. By introducing such a criterion, the Court of Justice arguably did meddle with the assignment of a legal classification to the actions brought, even though it had declared itself reluctant to do so. At least, the Court restricted the scope of restitutionary liability somewhat. It follows that, even though the legal classification of actions is generally a matter to be decided by the parties and national courts, and even though the Court of Justice has accepted that the scope of actions will overlap so that actions for repayment and damages will sometimes be simultaneously available to claimants, ${ }^{107}$ the Court may yet intervene and make clarifications when it considers itself compelled to do so.

Following FII, Advocate General Kokott recognized a criterion of "inevitable consequence" in connection to actions for repayment of charges levied in breach of EU law in her Opinion in Danfoss. The Advocate General noted that the assessment of what constitutes an inevitable consequence within the meaning of EU law is still rather shapeless and has only been applied in a very specific tax law context. Thus, the Advocate General implied, the holding in FII should perhaps be read on its facts. Nevertheless, Advocate General Kokott continued, the concept of inevitable consequence seemed in FII to be designed to delineate instances where it is possible to bring an action for repayment under EU law, from instances

\footnotetext{
${ }^{105}$ Judgment of 12 December 2006, Test Claimants in the FII Group Litigation, C-446/04, EU:C:2006:774, paragraphs 207-208. Having drawn these conclusions, the Court of Justice continued to offer guidance on EU law on liability in damages for Member States with regard to the heads of claim at issue.

${ }^{106}$ Judgment of 13 March 2007, Test Claimants in the Thin Cap Group Litigation, C-524/04, EU:C:2007:161, paragraphs 109-114.

${ }^{107}$ See Judgment of 22 April 1997, Sutton, C-66/95, EU:C:1997:207; Judgment of 14 January 1997, Comateb, joined cases C-192/95 - C-218/95, EU:C:1997:12; and Judgment of 12 December 2006, Test Claimants in the FII Group Litigation, C-446/04, EU:C:2006:774.
} 
where it is "only" possible to bring an action under the more stringent EU law conditions for Member State liability in damages. ${ }^{108}$ Further, in Accor, the "inevitable consequence test" was referred to and applied by Advocate General Mengozzi, but without much discussion. ${ }^{109}$

In practice the "inevitable consequence" construct seems intended to function as a test of the immediateness of the connection between a breach of EU law by the State and the corresponding frustration of the claimant's rights. Under the circumstances at hand in FII, the EU right to repayment of charges levied in breach of EU law did not apply since the event through which a loss arose was not an "inevitable consequence" of the event constituting a breach of EU law and through which the enrichment of the Member State arose. This implies that the Court endorsed the view that, in actions based on the EU right to repayment of charges, the private law doctrine of "indivisibility of origin" should apply. Under this doctrine an action for restitution is available only if both the enrichment and the corresponding impoverishment have flown from the same event. ${ }^{110}$ The inevitable consequence test could plausibly be more lenient than that, but the assessment of the Court nevertheless resulted in a rejection of restitutionary liability for the Member State. In FII the UK Revenue had unlawfully discriminated between resident and non-resident companies in its tax payment schemes. The losses incurred by the claimants, however, were held to have arisen from waivers of relief and increases in the amount of dividends distributed, both of which were decisions taken by the claimants. Even though these decisions had been reached in response to the unlawful aspects of the UK tax payment schemes, the Court of Justice found that they were not an inevitable consequence of them. In sum, the Court has demonstrated that it is no stranger to intervention if national criteria for access to a restitutionary remedy should be overly restrictive, but also that it would not intervene under the circumstances at hand in these cases.

\footnotetext{
${ }^{108}$ Opinion of AG Kokott of 24 March 2011, Danfoss, C-94/10, EU:C:2011:181, paragraph 43.

${ }^{109}$ Opinion of AG Mengozzi of 22 December 2010, Accor, C-310/09, EU:C:2010:813, paragraphs 75-78. In that case, which was similar to FII, AG Mengozzi concluded on the facts that the test was met. The issue did not arise in the final judgment of the Court of Justice.

${ }^{110}$ This doctrine of restitution or unjust enrichment law is explained in Cases, Materials and Texts on Unjustified Enrichment, ed. Jack Beatson and Eltjo Schrage (Oxford: Hart Publishing, 2003): 207. Indivisibility of origin is linked to the degree of "directness" with which the impoverishment and enrichment have flown from the transaction. It is not always easy to pinpoint this "directness". For an overview of European approaches to this problem in the context of private unjust enrichment law, see Draft Common Frame of Reference, Article VII. - 4:101.
} 
The inevitable consequence test has been criticised by Williams, who would advocate a more lenient test in order to extend further the scope of application of the EU right to repayment of charges levied in breach of EU law. ${ }^{111}$ Williams argued that the Court has undesirably instructed companies not to attempt to mitigate any loss incurred by the levy of unlawful charges, as such attempts would replace the unlawful levy as the origin of the loss, thereby rendering the loss unrecoverable by way of an action for repayment. ${ }^{112}$ Williams further argued that the ruling was unfortunate whereas the decision to take steps to mitigate the loss incurred were not voluntary, but forced upon the claimants by the unlawful tax regime. ${ }^{113}$ These arguments certainly have merit. However, in respect of loss in the form of an increase in dividends intended to compensate shareholders for the absence of tax credits, it can be counter argued that it would indeed have been better to leave it for the shareholders themselves to attempt to mitigate the losses incurred by them in respect of unlawfully withdrawn tax credits. Indeed, it seems in FII that the shareholders might have been able to bring a successful action for repayment against the State. ${ }^{114}$ It is another matter that the distributing company could not do so with regard to its increase of dividends. This was clearly expressed in the Opinion of Advocate General Geelhoed in FII:

...it does not seem to me that such actions on the part of the distributing company to increase the amount of distributions should be considered to be a direct consequence of the UK's unlawful failure to grant an equivalent credit to the shareholders. Rather, the direct consequence of this failure is simply the extra tax levied on those shareholders than would have been the case had the UK complied with its Community law obligations - which loss is suffered by the shareholders, and not the distributing companies. ${ }^{115}$

\footnotetext{
${ }^{111}$ Rebecca Williams, Unjust Enrichment and Public Law, 113-118.

${ }^{112}$ Ibid., 115.

${ }^{113}$ Ibid., 114.

${ }^{114}$ Cf. Opinion of AG Mengozzi of 22 December 2010, Accor, C-310/09, EU:C:2010:813, paragraphs 79-83, where the shareholders could not bring such an action. For that reason, and others, AG Mengozzi opined that the distributing company should be allowed to recover on behalf of its shareholders.

${ }^{115}$ Opinion of AG Geelhoed of 6 April 2006, Test Claimants in the FII Group Litigation, C-446/04, EU:C:2006:240, paragraph 133. For clarity, this line of argument does not apply to the other head of claim rejected by the Court of Justice, i.e., the waiver of relief in order to offset ACT in full, cf. Judgment of 12 December 2006, Test Claimants in the FII Group Litigation, C-446/04, EU:C:2006:774, paragraph 207.
} 
Under such circumstances, the nexus between the loss incurred by the distributing company and the denial of a tax credit for its shareholders does seem rather weak - too weak, as the Court of Justice consequently ruled, for the company to be able to include this head of claim in an action for repayment. The appropriate action should instead have been taken by the shareholders.

Similarly, Advocate General Kokott was skeptical as to whether the inevitable consequence test could be satisfied in Danfoss, where downstream claimants sought repayment of excise duties paid to the Member State by their suppliers and subsequently passed on to the claimants. Nonetheless, the Advocate General left a window open by indicating that the final decision depended on the proper interpretation of the test, which was as yet unclear. ${ }^{116}$ In Reemtsma the claimants also lacked a direct nexus with the Member State but were allowed by the Court of Justice to present their claim. In both cases, however, there was no mention of the inevitable consequence test in the reasoning of the Court. Instead the Court held that, under the circumstances, it would be contrary to the principle of effectiveness to oppose a repayment claim from downstream claimants, ${ }^{117}$ giving an impression of searching for equitable results on an ad hoc basis rather than developing criteria for the guidance of courts and litigants.

As is apparent from the above, the inevitable consequence test remains "rather vague" 118 and in need of further clarification of its scope and practical interpretation in future case law. It is submitted however that it serves a useful purpose and that it corresponds well to tendencies in European private law, as seen above. ${ }^{119}$ There will always be situations where the quality of the connection between a payment by the claimant and the incompatibility of national law with EU law will be called into question, and that is when guidance will be needed. Nevertheless it remains to be seen whether the inevitable consequence test will be developed by the Court of Justice or whether it will remain unconfirmed, floating dicta inspired by the need of defining the scope of the restitutionary action in particular instances.

Like its damages counterpart, causation, the inevitable consequence test - if it is a criterion for restitutionary liability of a Member State - will to

\footnotetext{
116 Opinion of AG Kokott of 24 March 2011, Danfoss, C-94/10, EU:C:2011:181, paragraphs 47-55. ${ }_{117}$ Judgment of 15 March 2007, Reemtsma, C-35/05, EU:C:2007:167, paragraphs 39-42; Judgment of 20 October 2011, Danfoss, C-94/10, EU:C:2011:674, paragraph 26-29. Cf. note 66.

${ }^{118}$ Opinion of AG Kokott of 24 March 2011, Danfoss, C-94/10, EU:C:2011:181, paragraph 43.

${ }^{119}$ See the discussion on "indivisibility of origin" in the text accompanying note 110.
} 
a large extent consist in an assessment of the facts and should therefore, by and large, be left to the national courts. Nonetheless national conditions such as limitations on admissible evidence or the like will be subject to scrutiny under the EU law principles of equivalence and effectiveness. Through scrutiny of such limitations by the Court of Justice, we may get more flesh to the meager bones of this test.

\section{Summary and conclusions}

Summarizing the analysis it is worth repeating again the criteria for restitutionary liability of Member States that have been extracted from the case law:

1. The existence of a substantive right conferred on the claimant by EU law,

2. The existence of a payment from the claimant, collected by or on behalf of the Member State,

3. The incompatibility of the basis of that payment with EU law, and

4. The payment following as an inevitable consequence of the breach of EU law by the Member State.

Among these criteria the first seems to be the least problematic. By contrast, it is very difficult to define the payment criterion with precision. First and foremost it is uncertain whether it is necessary that the payment at issue has finally been collected by the Member State. It is also uncertain whether or not this criterion could still be satisfied if the claimant has been impoverished in another manner than through a payment. It has therefore been discussed, but without reaching any clear conclusion, whether the payment criterion should be subdivided into two criteria: Impoverishment of the claimant and enrichment of the Member State. Similar difficulties pertain to the third criterion of incompatibility of the payment with EU law, but it has been submitted that this criterion is met if the basis for the payment, collected by or on behalf of the Member State, was incompatible with EU law. The inevitable consequence test is perhaps the most elusive, as it is even uncertain whether it applies at all. The case law is unclear, but it has been submitted that such a test serves a purpose.

As to whether and to what extent the criteria are governed by EU law or national law, respectively, it has been submitted that the first and third criteria must be governed by EU law (although interpretation of national 
law in the context of the third ultimately falls to the national court). The second and fourth criteria are basically assessments of facts and should be entrusted to the national courts, but national conditions such as limitations on admissible evidence or the like will remain subject to scrutiny under the EU law principles of equivalence and effectiveness. ${ }^{120}$

Some of the difficulties in the analysis could plausibly be overcome if the Court of Justice were to distinguish clear cases of repayment of charges levied by a Member State institution or agency in breach of EU law from more difficult cases of possible liability by reason of the unjust enrichment of Member States, where the enrichment is connected to an event which frustrates rights conferred on individuals by EU law. ${ }^{121}$ Cases such as Danfoss, Reemtsma and FII could (without prejudice to the merits of the claims in the respective cases) serve as examples of the latter category. Such a development remains open to the Court, but it would be necessary to elaborate on adjusted criteria for such liability, e.g. the impoverishment of the claimant, the enrichment of the Member State, and the precise character of the connection between the two that would be required. ${ }^{122}$

To conclude, the Court of Justice has not been as generous with clarifications of the criteria for restitutionary liability of Member States as it has been with criteria for damages liability for Member States, ${ }^{123}$ or even unjust enrichment liability of EU institutions. ${ }^{124}$ This search for lost criteria has nonetheless yielded a suggested set of applicable criteria, even though some of them remain vague or openly questionable. These conclusions are admittedly far from a madeleine and tea experience, bringing bright illumination of recognizable criteria for restitutionary liability. Perhaps they are more of a bleak cry in the desert. Will the Court hear?

\footnotetext{
${ }^{120}$ This author consequently endorses an approach of interaction of EU law, national law, and facts to be assessed by the national court. For an alternative view see Schlote, "The San Giorgio 'cause of action"', 113.

${ }^{121}$ Cf. the French distinction between répétition de l'indu and enrichissement sans cause, Rebecca Williams, Unjust Enrichment and Public Law, 172-176.

${ }^{122}$ See Draft Common Frame of Reference, Book VII, Chapter 4 for examples from European private law.

${ }^{123}$ Notably in Judgment of 8 October 1996, Dillenkofer, joined cases C-178/94, C-179/94, C-188/94, C-189/94 and C-190/94, EU:C:1996:375.

${ }^{124}$ See Judgment of 16 December 2008, Masdar, C-47/07 P, EU:C:2008:726.
} 


\section{Bibliography}

Aalto, Pekka. Public Liability in EU Law: Brasserie, Bergaderm and Beyond. Oxford: Hart Publishing, 2011.

Aalto, Pekka, Herwig C. H. Hofmann, Liisa Holopainen, Elina Paunio, Laurent Pech, Debbie Sayers, Dinah Shelton, and Angela Ward. "Article 47 - Right to an Effective Remedy and to a Fair Trial". In The EU Charter of Fundamental Rights: A Commentary, edited by Steve Peers, Tamara Hervey, Jeff Kenner and Angela Ward, 1197-1276. Munich: Verlag CH Beck/Oxford: Hart Publishing/Baden-Baden: Nomos, 2014.

Arnull, Anthony. The European Union and its Court of Justice. $2^{\text {nd }}$ ed. Oxford EC Law Library. Oxford: Oxford University Press, 2006.

Bar, Christian von, and Eric Clive (editors). Principles, Definitions and Model Rules of European Private Law: Draft Common Frame of Reference (DCFR) Full Edition. Munich: Sellier European Law Publishers, 2009.

Barnard, Catherine. The Substantive Law of the EU: The Four Freedoms. $5^{\text {th }}$ ed. Oxford: Oxford University Press, 2016.

Beatson, Jack, and Eltjo Schrage (editors). Cases, Materials and Texts on Unjustified Enrichment. Oxford: Hart Publishing, 2003.

Biondi, Andrea, and Lindsay Johnson. "The Right to Recovery of Charges levied in Breach of Community Law: No Small Matter". European Public Law 4, no. 3 (1998): 313-321.

Biondi, Andrea, and Martin Farley. The Right to Damages in European Law. Kluwer European Law Collection. Alphen aan den Rijn: Kluwer Law International, 2009.

Birks, Peter. Unjust Enrichment. $2^{\text {nd }}$ ed. Clarendon Law Series. Oxford: Oxford University Press, 2005.

Chambers, Robert, Charles Mitchell, and James Penner (editors). Philosophical Foundations of The Law of Unjust Enrichment. Oxford: Oxford University Press, 2009.

Dougan, Michael. National Remedies before the Court of Justice: Issues of Harmonisation and Differentiation. Modern Studies in European Law. Oxford: Hart Publishing, 2004.

Dougan, Michael. "The Vicissitudes of Life at the Coalface: Remedies and Procedures for Enforcing Union Law before the National Courts". In The Evolution of EU Law. $2^{\text {nd }}$ ed. Edited by Paul Craig and Gráinne de Búrca, 407-438. Oxford: Oxford University Press, 2011.

Dougan, Michael. "When Worlds Collide! Competing Visions of the Relationship between Direct Effect and Supremacy". Common Market Law Review 44, no. 4 (2007): 931-963.

Gerven, Walter van. "Of Rights, Remedies and Procedures". Common Market Law Review 37, no. 3 (2000): 501-536. 
Heukels, Ton, and Alison McDonnell (editors). The Action for Damages in Community Law. Alphen aan den Rijn: Kluwer Law, 1997.

Lenaerts, Koen, and Tim Corthaut. "Of Birds and Hedges: The Role of Primacy in Invoking Norms of EU Law”. European Law Review 31, no. 3 (2006): 287-315.

Lenaerts, Koen, Ignace Maselis, and Kathleen Gutman. EU Procedural Law, edited by Janek Tomasz Nowak. Oxford EU Law Library. Oxford: Oxford University Press, 2014.

Półtorak, Nina. European Union Rights in National Courts. Alphen aan den Rijn: Wolters Kluwer, 2015.

Prechal, Sacha. Directives in EC Law. $2^{\text {nd }}$ ed. Oxford EC Law Library. Oxford: Oxford University Press, 2006.

Prechal, Sacha, and Rob Widdershoven. "Effectiveness or Effective Judicial Protection:

A Poorly Articulated Relationship". In Today's Multi-layered Legal Order: Current Issues and Perspectives. Liber amicorum in honour of Arjen W.H. MEIJ, edited by Tristan Baumé, Edmon Oude Elferink, Pauline Phoa and Dominique Thiaville, 283296. Zutphen: Paris Legal Publishers, 2011.

Rush, Michael. The Defence of Passing On. Oxford: Hart Publishing, 2006.

Schlote, Maximilian. “The San Giorgio 'Cause of Action'”. British Tax Review 2014, no. 2 (2014): 103-113.

Smith, Lesley Jane. "A European Concept of Condictio Indebiti?”. Common Market Law Review 19, no. 2 (1982): 269-285.

Strand, Magnus. "Beyond the Competition Damages Directive: What Room for Competition Law Restitution?". In Harmonising EU Competition Litigation: The New Directive and Beyond, Swedish Studies in European Law vol. 8, edited by Maria Bergström, Marios Iacovides and Magnus Strand, 279-294. Oxford: Hart Publishing, 2016.

Strand, Magnus. The Passing-On Problem in Damages and Restitution under EU Law. Elgar European Law and Practice Series. Cheltenham: Edward Elgar Publishing, 2017. Ward, Angela. Judicial Review and the Rights of Private Parties in EU Law. $2^{\text {nd }}$ ed. Oxford: Oxford University Press, 2007.

Williams, Rebecca. Unjust Enrichment and Public Law: A Comparative Study of England, France and the UK. Oxford: Hart Publishing, 2011.

Witte, Bruno de. "Direct Effect, Primacy, and the Nature of the Legal Order". In The Evolution of EU Law. $2^{\text {nd }}$ ed. Edited by Paul Craig and Gráinne de Búrca, 323-362. Oxford: Oxford University Press, 2011.

Zimmermann, Reinhard. The Law of Obligations: Roman Foundations of the Civilian Tradition. Oxford: Oxford University Press, 1996.

Zweigert, Konrad, and Hein Kötz. An Introduction to Comparative Law. $3^{\text {rd }}$ ed. Oxford: Oxford University Press, 1998. 